\title{
In vivo selection of sfGFP variants with improved and reliable functionality in industrially important thermophilic bacteria
}

\author{
Elrike Frenzel ${ }^{1}$, Jelmer Legebeke ${ }^{1}$, Atze van Stralen ${ }^{1}$, Richard van Kranenburg ${ }^{2,3}$ and Oscar P. Kuipers ${ }^{1 *}$
}

\begin{abstract}
Background: Fluorescent reporter proteins (FP) have become an indispensable tool for the optimization of microbial cell factories and in synthetic biology per se. The applicability of the currently available FPs is, however, constrained by species-dependent performance and misfolding at elevated temperatures. To obtain functional reporters for thermophilic, biotechnologically important bacteria such as Parageobacillus thermoglucosidasius, an in vivo screening approach based on a mutational library of superfolder GFP was applied.
\end{abstract}

Results: Flow cytometry-based benchmarking of a set of GFPs, sfGFPs and species-specific codon-optimized variants revealed that none of the proteins was satisfyingly detectable in $P$. thermog/ucosidasius at its optimal growth temperature of $60^{\circ} \mathrm{C}$. An undirected mutagenesis approach coupled to fluorescence-activated cell sorting allowed the isolation of sfGFP variants that were extremely well expressed in the chassis background at $60^{\circ} \mathrm{C}$. Notably, a few nucleotide substitutions, including silent mutations, significantly improved the functionality and brightness. The best mutant sfGFP(N39D/A179A) showed an 885-fold enhanced mean fluorescence intensity (MFI) at $60^{\circ} \mathrm{C}$ and is the most reliable reporter protein with respect to cell-to-cell variation and signal intensity reported so far. The in vitro spectral and thermostability properties were unaltered as compared to the parental sfGFP protein, strongly indicating that the combination of the amino acid exchange and an altered translation or folding speed, or protection from degradation, contribute to the strongly improved in vivo performance. Furthermore, sfGFP(N39D/A179A) and the newly developed cyan and yellow derivatives were successfully used for labeling several industrially relevant thermophilic bacilli, thus proving their broad applicability.

Conclusions: This study illustrates the power of in vivo isolation of thermostable proteins to obtain reporters for highly efficient fluorescence labeling. Successful expression in a variety of thermophilic bacteria proved that the novel FPs are highly suitable for imaging and flow cytometry-based studies. This enables a reliable cell tracking and singlecell-based real-time monitoring of biological processes that are of industrial and biotechnological interest.

Keywords: GFP, sfGFP, Thermostability, Biotechnology, Parageobacillus sp., Geobacillus sp., Thermophilic bacteria, FACS, Protein engineering, In vivo application, Cyan, Yellow

\section{Background}

Among other thermophilic bacteria, the Gram-positive Parageobacillus and Geobacillus species receive increasing interest as platform organisms for industrial

\footnotetext{
*Correspondence: o.p.kuipers@rug.nl

${ }^{1}$ Department of Molecular Genetics, Groningen Biomolecular Sciences and Biotechnology Institute, Centre for Synthetic Biology, University of Groningen, Nijenborgh 7, 9747 AG Groningen, The Netherlands Full list of author information is available at the end of the article
}

biotechnology. Besides their exploitation for the identification and production of novel thermostable enzymes [1-4], these species are nowadays considered important chassis to build microbial cell factories for bioconversion and consolidated bioprocessing, particularly in biorefining applications based on renewable resources such as plant biomass $[5,6]$. Anticipated advantages of thermophilic organisms over mesophilic organisms are that their growth temperatures between 50 and $70{ }^{\circ} \mathrm{C}$ reduce the 
risk of contamination by mesophilic bacteria during fermentation processes, their reduced cooling costs, and the increased reaction rates at thermophilic temperatures. Additionally, the versatility of producing polysaccharidedegrading enzymes and their ability to use many different sugars make them attractive chassis organisms [7-12].

Parageobacillus thermoglucosidasius, which was originally described as Bacillus thermoglucosidasius [13] and Geobacillus thermoglucosidasius emended thermoglucosidans [14, 15], was recently taxonomically revised from the genus Geobacillus as monophyletic clade II organism [16]. This bacterium is of particular interest because it is a facultative anaerobe, with a mixed acid fermentation metabolism leading to the production of chemical building blocks such as lactate, formate, acetate, ethanol, and succinate.

In contrast to model organisms such as Bacillus subtilis, the development and application of tools for genetic manipulation of (Para)geobacillus species is still in its infancy. Lately, the improvement of transformation procedures $[7,17,18]$ paved the way for directed strain engineering. Though limited by the requirement of heat stability and reliable expression at high temperatures, an initial set of important tools has been established. This includes temperature-stable and temperature-sensitive cloning and integration vectors, antibiotic resistance marker genes (reviewed in $[19,20]$ ), natural, synthetic and inducible promoters and RBS [7, 21-23], and gene knock-out/knock-in systems [7, 24]. Among these tools, reporter genes with an easy and highly sensitive readout mode such as fluorescent proteins (FP) are of special interest. Their biotechnological applicability is broad, ranging from biosensors to output elements to assess the strength of promoter elements, which allows monitoring of flux changes or the redirection of metabolic fluxes during production processes $[25,26]$.

The first described and thoroughly analyzed FP is the $27-k D a$ green fluorescent protein (GFP), composed of 238 amino acids, which was isolated from the jellyfish Aequorea victoria [27, 28]. Its intrinsic fluorescence with an excitation maximum of $395 \mathrm{~nm}$ and an emission maximum at $509 \mathrm{~nm}$ emanates from a chromophore that resides in a kinked alpha-helix, surrounded by a betabarrel structure. The beta-can is composed of 11 strongly interacting beta-strands and protects the inner microenvironment with flexible loops and lids (reviewed in [29]). The side chains of amino acids that are facing inside the barrel and interact with the chromophore, determine not only the spectroscopic features but also the structural stability (reviewed in [30]). The beta-barrel structure is folded before the chromophore itself is formed by autocatalytic cyclisation, dehydration and oxidation steps of the tripeptide Ser65-Tyr66-Gly67 [29]. Thus, fluorescence reflects a properly folded scaffold and a mature chromophore and is, therefore, a measure for the proper folding state of the protein in vitro and in vivo.

Due to their versatile applicability, a palette of more than 40 different FP variants is available nowadays [31]. These proteins have either been generated from the $A$. victoria GFP or were isolated from different species such as corals and anthozoa and further optimized for expression in eukaryotes and/or prokaryotes. These range from blue to far-red color varieties to $\mathrm{pH}$ and redox sensors, $\mathrm{Ca}^{2+}$-detectors, photoswitchable and timer proteins and many more, and are applied dependent on the target of research, the host organism and the compatibility of excitation and emission maxima to fluorescence detection techniques (for reviews, see [32-34]). Heterologous expression of FPs, however, has certain limitations. Previous studies showed that the performance is species dependent [35], which is presumed to be primarily based on the codon usage frequency of the respective organism. Moreover, especially the factor temperature has profound effects on FP performance in vivo, since the majority of FPs was derived from eukaryotes that thrive in colder habitats. It was independently reported that, despite successful construction of GFP reporter strains, fluorescence signals could not be detected in thermophilic pro- and eukaryotes grown above $45^{\circ} \mathrm{C}[36,37]$. The temperature sensitivity of wild-type GFP is restricted to the folding process, since low-temperature exposed and properly folded proteins remain fluorescent to at least $65^{\circ} \mathrm{C}$ [29]. Consequently, a fast and robust folding GFP derivative was developed and termed 'superfolder' sfGFP [38]. The introduction of folding and solubility-enhancing mutations yielded a protein that folds well even when fused to poorly folded polypeptides, has increased in vitro thermal stability and shows superior resistance against chemical denaturants in comparison to conventional GFPs [38]. Additional attempts were made to obtain thermostable mutants by rational engineering of GFP [39]. The characteristics of these variants were only tested with the purified proteins in in vitro assays, which do not provide insights into their in vivo functionality. A few recent studies reported on the in vivo use of sfGFP variants as output in thermophilic Geobacillus species [22, 23, 40]. However, the efficiency of FP expression at the singlecell level and thus the dynamic range of expression were not studied. To perform meaningful quantification of promoter activity changes in single cells or cell populations, it is of importance that the fluorescence intensity of a biomarker remains constant and has narrow signal amplitude.

To develop a reporter protein suitable for the expression in Gram-positive thermophilic hosts, we first benchmarked the performance of a set of FPs in $P$. 
thermoglucosidasius DSM 2542 by flow cytometry. We further employed a random mutagenesis approach of the best performing FP variant coupled to fluorescence-activated cell sorting for isolating brightly expressed mutants in the chassis background at $60^{\circ} \mathrm{C}$. This in vivo selection approach resulted in the identification of several thermostable variants. One highly thermostable version with improved brightness, sfGFP(N39D/A179A), was further engineered to generate color variants as well as analyzed for its suitability of usage in additional thermophilic species.

\section{Methods}

\section{Bacterial strains and growth media}

The bacterial strains used in this study are listed in Table 1. E. coli was routinely grown in lysogeny broth (LB) containing $10 \mathrm{~g} / \mathrm{L}$ tryptone (Oxoid), $5 \mathrm{~g} / \mathrm{L} \mathrm{NaCl}$ and $5 \mathrm{~g} / \mathrm{L}$ yeast extract $(\mathrm{Carl}$ Roth $\mathrm{GmbH})$ at $37{ }^{\circ} \mathrm{C}$. Plates were prepared with $15 \mathrm{~g} / \mathrm{L}$ of agar. When required, the following antibiotics were added: chloramphenicol $(15 \mu \mathrm{g} / \mathrm{mL})$, ampicillin $(100 \mu \mathrm{g} / \mathrm{mL})$, and kanamycin $(50 \mu \mathrm{g} / \mathrm{mL})$.

B. smithii was grown in LB2 broth, $\mathrm{pH} 7.0$ [41], consisting of $10 \mathrm{~g} / \mathrm{L}$ tryptone (Becton-Dickinson), $5 \mathrm{~g} / \mathrm{L}$ yeast extract (Carl Roth $\mathrm{GmbH}$ ), and $100 \mathrm{~mL} / \mathrm{L} 10 \times \mathrm{ESS}$ $\left(2.3 \mathrm{~g} / \mathrm{L} \mathrm{K}_{2} \mathrm{HPO}_{4}, 5.1 \mathrm{~g} / \mathrm{L} \mathrm{NH}_{4} \mathrm{Cl}, 50.0 \mathrm{~g} / \mathrm{L} \mathrm{NaCl}, 14.7 \mathrm{~g} / \mathrm{L}\right.$ $\mathrm{Na}_{2} \mathrm{SO}_{4}, 0.8 \mathrm{NaHCO}_{3}, 2.5 \mathrm{~g} / \mathrm{L} \mathrm{KCl}, 18.7 \mathrm{~g} / \mathrm{L} \mathrm{MgCl} \cdot 6 \mathrm{H}_{2} \mathrm{O}$, $\left.4.1 \mathrm{~g} / \mathrm{L} \mathrm{CaCl}{ }_{2} \cdot 2 \mathrm{H}_{2} \mathrm{O}\right)$. B. coagulans was cultivated in $\mathrm{BC}$ broth, pH 6.5 [42], containing $10 \mathrm{~g} / \mathrm{L}$ glycine, $10 \mathrm{~g} / \mathrm{L}$ yeast extract (Carl Roth $\mathrm{GmbH}), 10 \mathrm{~g} / \mathrm{L}$ Bis-Tris buffer, $2 \mathrm{~g} / \mathrm{L}\left(\mathrm{NH}_{4}\right)_{2} \mathrm{HPO}_{4}, 3.5 \mathrm{~g} / \mathrm{L}\left(\mathrm{NH}_{4}\right)_{2} \mathrm{SO}_{4}$, and $1 \mathrm{~mL} / \mathrm{L}$ trace elements solution $\left(5 \mathrm{~g} / \mathrm{L} \mathrm{MgCl}_{2}, 3 \mathrm{~g} / \mathrm{L} \mathrm{CaCl}_{2}\right.$, $0.05 \mathrm{~g} / \mathrm{L} \mathrm{ZnCl}, 0.03 \mathrm{~g} / \mathrm{L} \mathrm{MnCl}_{2} \cdot 4 \mathrm{H}_{2} \mathrm{O}, 0.3 \mathrm{~g} / \mathrm{L} \mathrm{H} \mathrm{H}_{2} \mathrm{BO}$, $0.2 \mathrm{~g} / \mathrm{L} \mathrm{CoCl}_{2} \cdot 6 \mathrm{H}_{2} \mathrm{O}, 0.01 \mathrm{~g} / \mathrm{L} \mathrm{CuCl}_{2} \cdot 2 \mathrm{H}_{2} \mathrm{O}, 0.02 \mathrm{~g} / \mathrm{L}$ $\left.\mathrm{NiSO}_{4} \cdot 6 \mathrm{H}_{2} \mathrm{O}, 0.03 \mathrm{~g} / \mathrm{L} \mathrm{Na} \mathrm{NoO}_{4} \cdot 2 \mathrm{H}_{2} \mathrm{O}\right)$. B. methanolicus was grown in BM medium (DSMZ Medium No. 1192) at $\mathrm{pH} 7.0(37.4 \mathrm{~g} / \mathrm{L}$ marine broth (Difco), $0.02 \mathrm{~g} / \mathrm{L}$ biotin, $0.001 \mathrm{~g} / \mathrm{L}$ vitamin $\mathrm{B}_{12}$, and $4 \mathrm{~mL} / \mathrm{L}$ methanol). $P$. thermoglucosidasius was cultivated in TGP broth [21], $\mathrm{pH} 7.0$ (17 g/L tryptone (Oxoid), $3 \mathrm{~g} / \mathrm{L}$ soy peptone (Oxoid), $5 \mathrm{~g} / \mathrm{L} \mathrm{NaCl}, 2.5 \mathrm{~g} / \mathrm{L} \mathrm{K}_{2} \mathrm{HPO}_{4}$, and post-autoclaved addition of filter-sterilized pyruvate and glycerol to final concentrations of $4 \mathrm{~g} / \mathrm{L}$ and $4 \mathrm{~mL} / \mathrm{L})$. G. thermodenitrificans was grown in LB2D broth, $\mathrm{pH} 7.0(10 \mathrm{~g} / \mathrm{L}$ tryptone (Becton-Dickinson), $10 \mathrm{~g} / \mathrm{L} \mathrm{NaCl}, 5 \mathrm{~g} / \mathrm{L}$ yeast extract (Carl Roth $\mathrm{GmbH}), 100 \mathrm{~mL} / \mathrm{L} 10 \times \mathrm{ESS}(2.5 \mathrm{~g} / \mathrm{L}$ $\mathrm{K}_{2} \mathrm{HPO}_{4}, 10 \mathrm{~g} / \mathrm{L} \mathrm{NH} \mathrm{Nl}_{4} \mathrm{Cl}, 30 \mathrm{~g} / \mathrm{L} \mathrm{NaCl}, 15 \mathrm{~g} / \mathrm{L} \mathrm{Na}_{2} \mathrm{SO}_{4}$, $0.8 \mathrm{~g} / \mathrm{L} \mathrm{NaHCO}, 10 \mathrm{~g} / \mathrm{L} \mathrm{KCl}, 18 \mathrm{~g} / \mathrm{L} \mathrm{MgCl}_{2} 6 \mathrm{H}_{2} \mathrm{O}, 3 \mathrm{~g} / \mathrm{L}$ $\mathrm{CaCl}_{2} 2 \mathrm{H}_{2} \mathrm{O}$ ).

If not stated otherwise, cells were first pre-grown from glycerol stocks for $16 \mathrm{~h}$ in their respective growth medium and then 1:100 diluted into fresh medium in a $1 / 10$ th volume of the growth flasks. To grow the strains on plates, above-stated broths were solidified with $5 \mathrm{~g} / \mathrm{L}$ gelrite (Carl Roth $\mathrm{GmbH}$ ).

\section{Transformation procedures for thermophilic bacteria}

One hundred milliliters of pre-warmed, strain-specific broth was inoculated from pre-cultures as follows: LB2 was inoculated with B. smithii to an OD600 of 0.08 and shaken at $55^{\circ} \mathrm{C}, 130 \mathrm{rpm}$; $\mathrm{BC}$ broth was inoculated with B. coagulans at an OD600 of 0.10 and shaken at $45{ }^{\circ} \mathrm{C}$, $120 \mathrm{rpm}$; SOBsuc broth was inoculated with $B$. methanolicus to an OD600 of 0.01 and shaken at $50{ }^{\circ} \mathrm{C}, 170 \mathrm{rpm}$; TGP was inoculated with $P$. thermoglucosidasius to an OD600 of 0.05 and shaken at $60{ }^{\circ} \mathrm{C}, 170 \mathrm{rpm}$; and LB2D was inoculated with $G$. thermodenitrificans to an OD600 of 0.1 and aerated at $55{ }^{\circ} \mathrm{C}, 140 \mathrm{rpm}$.

The cells were grown until the following optical densities were reached: $B$. smithii and B. coagulans OD600 of 0.5, B. methanolicus OD600 of 0.25 , and P. thermoglucosidasius and G. thermodenitrificans OD600 of 1.0. The cells were centrifuged in pre-chilled 50-mL tubes: B. smithii: $15 \mathrm{~min}, 4700 \mathrm{rpm}, 4{ }^{\circ} \mathrm{C}$; B. coagulans: $10 \mathrm{~min}$, $6000 \mathrm{rpm}, 4{ }^{\circ} \mathrm{C}$; B. methanolicus after $5 \mathrm{~min}$ on ice: 5 min, $3000 \times g, 4{ }^{\circ} \mathrm{C}$; P. thermoglucosidasius after $10 \mathrm{~min}$

Table 1 Bacterial strains used in this study

\begin{tabular}{lll}
\hline Bacterial strains & Relevant genotype & Source/reference \\
\hline Escherichia coli Top10 & General cloning host & Invitrogen \\
Escherichia coli BL21(DE3) & Protein expression host & MolGen strain collection \\
Bacillus smithii DSM 4216 & Wild-type & DSMZ, Germany \\
Bacillus coagulans DSM 1 & Wild-type & DSMZ, Germany \\
Bacillus methanolicus DSM 16454 & Wild-type & DSMZ, Germany \\
Parageobacillus thermoglucosidasius DSM 2542 & Wild-type & DSMZ, Germany \\
Geobacillus thermodenitrificans DSM 465 & Wild-type & DSMZ, Germany \\
Geobacillus thermodenitrificans T12 & Wild-type & {$[80]$}
\end{tabular}


on ice: $10 \mathrm{~min}, 5000 \mathrm{rpm}, 4{ }^{\circ} \mathrm{C}$; and G. thermodenitrifcans after $5 \mathrm{~min}$ on ice: $15 \mathrm{~min}, 4700 \mathrm{rpm}, 4{ }^{\circ} \mathrm{C}$. The cell pellets were resuspended in $50 \mathrm{~mL}$ SG buffer $(171.2 \mathrm{~g} / \mathrm{L}$ sucrose, $0.2 \mathrm{~g} / \mathrm{L} \mathrm{MgCl}_{2} \cdot \mathrm{H}_{2} \mathrm{O}, 50 \mathrm{~mL} / \mathrm{L}$ glycerol) for $B$. smithii; $50 \mathrm{~mL}$ EPB buffer $\left(0.68 \mathrm{~g} / \mathrm{L} \mathrm{KH}_{2} \mathrm{PO}_{4}, 72.8 \mathrm{~g} / \mathrm{L}\right.$ sorbitol, $0.8 \mathrm{~g} / \mathrm{L} \mathrm{MgCl}_{2}, 100 \mathrm{~mL} / \mathrm{L}$ glycerol, $\mathrm{pH} 4.5$ ) for $B$. coagulans; $3.5 \mathrm{~mL}$ EP buffer $(0.476 \mathrm{~g} / \mathrm{L}$ HEPES, $250 \mathrm{~g} / \mathrm{L}$ PEG 8000, pH 7.0) for B. methanolicus; $50 \mathrm{~mL}$ EPO buffer $(91 \mathrm{~g} / \mathrm{L}$ sorbitol and mannitol, $117.2 \mathrm{~mL} / \mathrm{L}$ $85 \%$ glycerol) for P. thermoglucosidasius; and $50 \mathrm{~mL}$ EPO2 buffer (MilliQ plus 10\% glycerol) for G. thermodenitrificans. Subsequently, cells were centrifuged and resuspended again in the following volumes: $B$. smithii 50, 25, and $12.5 \mathrm{~mL} \mathrm{SG}$ buffer $\left(4^{\circ} \mathrm{C}, 15 \mathrm{~min}, 4700 \mathrm{rpm}\right)$; B. coagulans 25 and $12.5 \mathrm{~mL}$ EPB buffer $\left(4{ }^{\circ} \mathrm{C}, 10 \mathrm{~min}\right.$, $6000 \mathrm{rpm}) ; \mathrm{B}$. methanolicus $3.5 \mathrm{~mL}$ EP buffer $\left(4{ }^{\circ} \mathrm{C}\right.$, 5 min, $3000 \times g$ ); $P$. thermoglucosidasius 25, 10, and $10 \mathrm{~mL}$ EPO buffer $\left(4{ }^{\circ} \mathrm{C}, 10 \mathrm{~min}, 6000 \mathrm{rpm}\right)$; and G. thermodenitrificans 50,25 , and $10 \mathrm{~mL}$ EPO2 buffer $\left(4{ }^{\circ} \mathrm{C}\right.$, $15 \mathrm{~min}, 4700 \mathrm{rpm}$ ). The final pellets were resuspended and aliquots were stored at $-80{ }^{\circ} \mathrm{C}$ : B. smithii $240 \mu \mathrm{L}$ SG buffer divided into $75 \mu \mathrm{L}$ aliquots; $B$. coagulans $1 \mathrm{~mL}$ EPB buffer divided into $100 \mu \mathrm{L}$ aliquots; $B$. methanolicus $200 \mu \mathrm{L}$ EP buffer divided into $100 \mu \mathrm{L}$ aliquots; $P$. thermoglucosidasius $750 \mu \mathrm{L}$ EPO buffer divided into $65 \mu \mathrm{L}$ aliquots; and G. thermodenitrificans $900 \mu \mathrm{L}$ EPO2 buffer divided into $65 \mu \mathrm{L}$ aliquots.

For electroporation, $1 \mu \mathrm{g}$ of plasmid DNA was added to the aliquots of competent thermophilic bacteria. Different electroporation cuvette gap sizes were used: $0.1 \mathrm{~cm}$ for B. smithii and P. thermoglucosidasius and $0.2 \mathrm{~cm}$ for $G$. thermodenitrificans, B. methanolicus, B. coagulans and G. stearothermophilus. The following electroporation settings were used: B. smithii $1.5 \mathrm{kV}, 25 \mu \mathrm{F}, 600 \Omega$; B. coagulans $1.6 \mathrm{kV}, 25 \mu \mathrm{F}, 200 \Omega$; B. methanolicus and G. thermodenitrificans $2.5 \mathrm{kV}, 25 \mu \mathrm{F}, 200 \Omega$; and P. thermoglucosidasius $2.5 \mathrm{kV}, 10 \mu \mathrm{F}, 600 \Omega$.

After pulsing, cells were inoculated in $1 \mathrm{~mL}$ prewarmed culture media and incubated under the following conditions: B. smithii $55{ }^{\circ} \mathrm{C}, 150 \mathrm{rpm}, 3 \mathrm{~h}$ in ME2 broth; $B$. coagulans $45^{\circ} \mathrm{C}, 160 \mathrm{rpm}, 3 \mathrm{~h}$ in RM medium, B. methanolicus first $45^{\circ} \mathrm{C}, 120 \mathrm{rpm}, 2 \mathrm{~h}$ and then $50^{\circ} \mathrm{C}$, $200 \mathrm{rpm}, 4 \mathrm{~h}$ in SOBsuc medium; $P$. thermoglucosidasius $52{ }^{\circ} \mathrm{C}, 140 \mathrm{rpm}, 2 \mathrm{~h}$ in TGP broth, and G. thermodenitrificans $55^{\circ} \mathrm{C}, 140 \mathrm{rpm}, 2 \mathrm{~h}$ in LB2D medium. Afterwards, cells were plated and incubated on the following growth media: B. smithii at $55^{\circ} \mathrm{C}$ on LB2 containing $7 \mu \mathrm{g} / \mathrm{mL}$ chloramphenicol; B. coagulans at $45^{\circ} \mathrm{C}$ on $\mathrm{BC}$ containing $5 \mu \mathrm{g} / \mathrm{mL}$ chloramphenicol B. methanolicus at $50{ }^{\circ} \mathrm{C}$ on BM with $5 \mu \mathrm{g} / \mathrm{mL}$ chloramphenicol; $P$. thermoglucosidasius at $52{ }^{\circ} \mathrm{C}$ on TGP with $10 \mu \mathrm{g} / \mathrm{mL}$ chloramphenicol; G. thermodenitrificans at $55{ }^{\circ} \mathrm{C}$ on LB2 with $5 \mu \mathrm{g} / \mathrm{mL}$ chloramphenicol.

\section{Recombinant DNA techniques}

DNA isolation, manipulation and transformation of $E$. coli were carried out according to standard procedures [43]. All enzymes were obtained from Thermo Fisher Scientific. Phusion High-Fidelity DNA polymerase was used for cloning and sequencing purposes and the DreamTaq polymerase for colony PCR. Plasmid constructs were verified by double-strand DNA sequencing (Macrogen).

\section{Colony PCR of thermophilic bacteria}

Colonies were resuspended in $200 \mu \mathrm{L}$ MilliQ water, vortexed and centrifuged for $2 \mathrm{~min}$ at $12,000 \mathrm{rpm}$. To the cell pellet, $100 \mu \mathrm{L}$ InstaGene Matrix (Bio-Rad) was added and the samples were incubated for $30 \mathrm{~min}$ at $55^{\circ} \mathrm{C}$. After vortexing, the cells were lysed by incubation at $100{ }^{\circ} \mathrm{C}$ for $8 \mathrm{~min}$ and the cell debris was removed by centrifugation (3 $\mathrm{min}, 13,000 \mathrm{rpm}$ ). The DNA-containing supernatant was subsequently used for PCR with plasmid-specific oligos pNW33N_for and pNW33N_rev (for oligonucleotides used in this study, see Additional file 1: Table S1).

\section{Construction of FP expression plasmids}

All oligonucleotides and plasmids used in this study are listed in Additional files 1 and 2: Tables S1, S2, respectively. To generate the E. coli-Geobacillus shuttle vector pNW-Ppta-3TER, the pta promoter was amplified with the oligonucleotides Ppta_for and Ppta_rev from genomic DNA of $P$. thermoglucosidasius DSM 2542. The fragment was cut with EcoRI and SmaI and cloned into the equally cut pNW33N backbone. The threefold terminator was amplified from plasmid pKB01-sfGFP(Sp) using the oligonucleotide pair 3TER_for and 3TER_rev, cut with SphI and HindIII and cloned into the SphI and HindII digested plasmid pNW-P $\mathrm{pta}_{\text {. The }}$ pNW-P $\mathrm{pta}-\mathrm{FP}-$ 3TER vectors containing FPs (Additional file 2) were constructed by amplification of the respective GFP genes while incorporating a $5^{\prime}$ end $\mathrm{XbaI}$ site and a $3^{\prime}$ end $S p h \mathrm{I}$ site: the gfpmut $3 A$ gene was amplified with primers GFPmut3A_for and GFPmut3A_rev from pAD123; gfpuv was amplified with primers GFPuv_for and GFPuv_rev from pSG1156; sfGFP_Gst_F and sfGFP_Gst_R were used for amplification of $s f G F P(G s t)$ from PRHIII-sfGFPpNW33N; and $g f p+, g f p(S p), s f g f p(B s), s f g f p(S p)$ and $s f g f p(i G E M)$ were amplified with the primer pair pKB01_ FP_for and pKB01_FP_rev from the respective plasmids of the pKB01 series (Additional file 2: Table S2). After restriction with $X b a \mathrm{I}$ and $S p h \mathrm{I}, \mathrm{PCR}$ fragments were ligated into the $\mathrm{XbaI}$ and $S p h \mathrm{I}$ cut $\mathrm{pNW}-\mathrm{P}_{\mathrm{pta}}$-FP-3TER backbone.

Color variants of the thermostable sfGFPS70 protein were engineered by site-directed mutagenesis PCR. To introduce the cyan Y66W mutation, the $5^{\prime}$ end of sfGFP(N39D/A179A) was amplified with the primer 
pair sfGFP_Xba_F and sfGFP_Y66W_R and the $3^{\prime}$ end was amplified with sfGFP_Y66W_F and sfGFP_Sph_R (Additional file 1: Table S1). Purified PCR fragments were mixed in equimolar amounts and used as a template in a PCR using the primers sfGFP_Xba_F and sfGFP_Sph_R. For introducing the yellow T203Y mutation, the primer pairs sfGFP_Xba_F/sfGFP_T203Y_R and sfGFP_T203Y_F/sfGFP_Sph_R were used. The final amplification products were cut with $X b a \mathrm{I}$ and $S p h \mathrm{I}$ and cloned into pNW-P $\mathrm{pta}$-3TER, which was cut with the same enzymes, giving rise to pNW-sfCFPS102 and pNW-sfYFPS102.

For expression in E. coli and in vitro analysis of the proteins, FPs were amplified with the primers LICv1sfGFP_Fs and LICv1sfGFP_Rs using the plasmids pNW-sfGFP(Sp), pNW-sfGFP(N39D/A179A), pNW-sfGCPS102 and pNW-sfYFPS102 as the template. Ligation-independent cloning into the plasmid pETHis6TEVLic (1B) was performed as described previously [44], thereby placing the FPs downstream of an IPTG-inducible promoter and of a TEV protease-cleavable $\mathrm{His}_{6}$ tag for affinity purification.

\section{Generation of sfGFP(Sp) mutational library}

The sfGFP(Sp) gene was randomly mutagenized using the GeneMorph II Random Mutagenesis Kit (Agilent Genomics) according to the manufacturers' instruction. The primers pKB01derMut_F and pKB01derMut_R were designed to contain a $\mathrm{Xba \textrm {I }}$ and a $S p h \mathrm{I}$ restriction site and to leave the start codon and the three stop codons of the $s f G F P(S p)$ gene intact, respectively. The amplified fragments were digested with $X b a \mathrm{I}$ and $S p h \mathrm{I}$ and ligated into $\mathrm{pNW}-\mathrm{P}_{\text {pta }}$-3TER, downstream of the constitutive $p t a$ promoter of $P$. thermoglucosidasius DSM 2542. Ligation products were transformed by electroporation $(25 \mu \mathrm{F}$, $200 \Omega, 2.5 \mathrm{kV} ; 0.2$-mm cuvettes) into $40 \mu \mathrm{L}$ aliquots of electrocompetent $E$. coli Top10, yielding a final library size of 125,000 clones. To determine the mutation frequency, twenty randomly selected colonies were used for plasmid isolation and sequencing with the primers pNW33N_for and pNW33N_rev. All E. coli Top10 colonies were pooled by washing the colonies with $10 \mathrm{~mL}$ of LB-Cm 15 medium from the transformation plates. Fifty milliliters of the cell suspension was pelleted $\left(4^{\circ} \mathrm{C}, 5 \mathrm{~min}\right.$, $6000 \mathrm{~g}$ ) and used for isolation of the plasmid pool with the Jetstar Plasmid Purification Midi kit (Genprice) for transformation of $P$. thermoglucosidasius DSM 2542.

\section{Isolation of temperature-stable GFP variants} by fluorescence-activated cell sorting (FACS) of $P$. thermoglucosidasius

Before sorting, the sample line was sterilized with $75 \%$ $\mathrm{EtOH}$ for $5 \mathrm{~min}$. Cells grown to mid-exponential growth phase $\left(\mathrm{OD}_{600}=1.5-2.5\right)$ were diluted into sterile filtered, $65{ }^{\circ} \mathrm{C}$-pre-warmed PBS buffer, $\mathrm{pH}$ 7.0, and instantly subjected to FACS with a FACS Aria II (Becton-Dickinson). Samples were sorted using a $70-\mu \mathrm{m}$ nozzle choosing the highest purity setting (yield mask: 0, purity mask: 32, phase mask: 0$)$. The population was gated by forward scatter $(488 / 10 \mathrm{~nm})$, side scatter $(488 / 10 \mathrm{~nm})$, and by the GFP emission (ex 525/50 nm, $505 \mathrm{~nm} \mathrm{LP} \mathrm{fil-}$ ter) windows (all in log scale). Libraries grown at $60{ }^{\circ} \mathrm{C}$ were sorted with a narrow gate (GFP-A $\left.10^{4}-2 \times 10^{5}\right)$, thereby isolating clones from the $0.1 \%$ subgroup of highest fluorescence of population. Libraries grown at $65{ }^{\circ} \mathrm{C}$ were sorted with a broader gate (GFP-A $10^{3}-2 \times 10^{5}$ ), thereby isolating $2.0 \%$ of population corresponding of highly fluorescent clones. Approximately 100,000 clones were sorted into $5 \mathrm{~mL}$ of TGP medium containing $10 \mu \mathrm{g} /$ $\mathrm{mL}$ chloramphenicol. From these, $100 \mu \mathrm{L}$ were plated directly on TGP-Cm10 plates and incubated at $60^{\circ} \mathrm{C}$ for subsequent analysis by colony fluorescence imaging. The remaining cells were used to inoculate $50 \mathrm{~mL}$ of fresh TGP-Cm10 medium and grown at 60 or $65{ }^{\circ} \mathrm{C}$ in 250 $\mathrm{mL}$ baffled flasks for $16 \mathrm{~h}$. In total, two iterative rounds of sorting, outgrowth and repeated isolation of brightest clones were performed at 60 and $65^{\circ} \mathrm{C}$.

\section{Colony fluorescence imaging}

Fluorescence signals of plate-grown colonies were captured using an Olympus MVX10 MacroZoom fluorescence microscope equipped with a PreciseExcite LED fluorescence illuminator (470 nm), a GFP filter set (ex 460/480 nm and em 495/540 nm), and an Olympus XM10 monochrome camera.

\section{Fluorescence microplate assay}

DSM 2542 cultures were grown at $45-60{ }^{\circ} \mathrm{C}$ in TGP broth with $10 \mu \mathrm{g} / \mathrm{mL}$ chloramphenicol as described above. Every $30 \mathrm{~min}, 200 \mu \mathrm{L}$ of cells were transferred to a microtiter plate and the fluorescence was recorded in the topreading mode with an Infinite 200 plate reader (Tecan Group) equipped with a GFP filter set (ex $485 / 20 \mathrm{~nm}$, em $535 / 25 \mathrm{~nm}$ ). The GFP signals were corrected for OD600, background fluorescence of the broth, and for autofluorescence (wild-type cells) as previously described [35].

\section{Flow cytometry (FC) of $P$. thermoglucosidasius}

Single-cell fluorescence measurements were made with a FACSCanto flow cytometer (BD Biosciences) with $488 \mathrm{~nm}$ excitation from a $20 \mathrm{~mW}$ solid-state laser. Geobacillus pre-cultures were obtained by inoculating $10 \mathrm{~mL}$ TGP supplemented with $8 \mu \mathrm{g} / \mathrm{mL}$ chloramphenicol from glycerol stocks and incubation at $60{ }^{\circ} \mathrm{C}$ and $170 \mathrm{rpm}$. After $16 \mathrm{~h}$, cells were diluted to an OD600 of 0.08 into $25 \mathrm{~mL}$ pre-warmed, fresh TGP-Cm8 in $250-\mathrm{mL}$ 


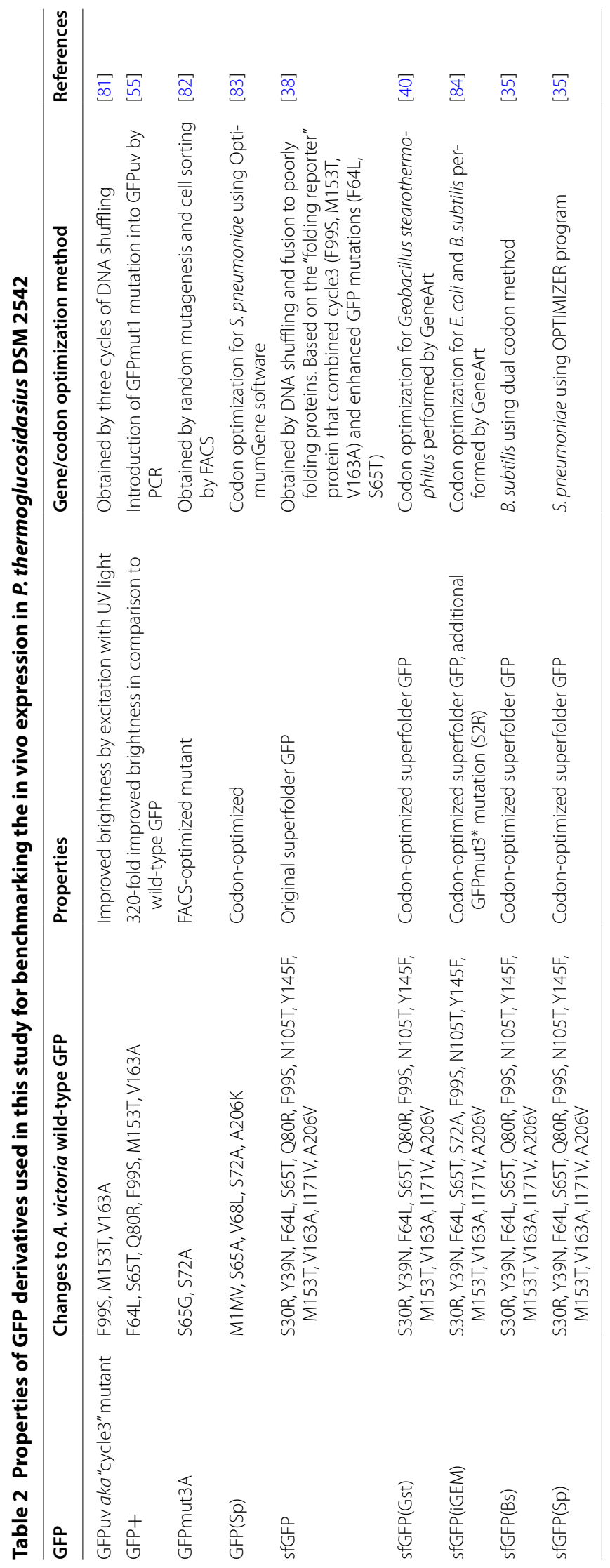


baffled flasks, and incubated at the desired temperatures at $170 \mathrm{rpm}$. Samples taken after specific time intervals (1, $2,4,6,8,10$ and $12 \mathrm{~h}$ ) or at an OD600 of 1.0 were immediately diluted (at least 1:100) with pre-warmed phosphate buffer solution (PBS, pH 7.0). Per sample, 100,000 events were recorded by measuring the fluorescence at $530 \mathrm{~nm} / 30 \mathrm{~nm}$ band-pass width. The instrument settings were as follows: threshold-SSC 200, FCS 200, FL1 600 V, all in log amplification. The data were captured with the BD FACSdiva software (version 5.0.3) and for data analysis Flowing Software (version 2.5.1) and FCSalyzer (version 0.9.13) were used.

\section{Fluorescence microscopy}

Strains containing the $\mathrm{pNW}-\mathrm{P}_{\mathrm{pta}}$-FP plasmids (Additional file 2) were grown for $16 \mathrm{~h}$ on solid media (B. smithii LB2 plates with $5 \mu \mathrm{g} / \mathrm{mL}$ chloramphenicol at $55{ }^{\circ} \mathrm{C}, B$. coagulans BC plates with $9 \mu \mathrm{g} / \mathrm{mL}$ chloramphenicol and $B$. methanolicus BM plates with $5 \mu \mathrm{g} / \mathrm{mL}$ chloramphenicol at $45{ }^{\circ} \mathrm{C}$, and P. thermoglucosidasius and G. thermodenitrificans on TGP plates with $8 \mu \mathrm{g} / \mathrm{mL}$ chloramphenicol at $60{ }^{\circ} \mathrm{C}$ ). Cells were resuspended in PBS and transferred to a microscope slide coated with $2 \%$ PBS-agarose. Alternatively, cells from liquid cultures were spotted on the agarose slides. Images were taken using a Deltavision Elite microscope (Applied Precision) with a sCMOS camera and SSI Solid-State Illumination (Applied Precision) through a $100 \times$ oil immersion objective (phase contrast) and $50 \mathrm{~mW}$ laser illumination for fluorescence combined with Quad (for GFP) or C/YFP/mCH (for CFP and YFP) polychroic filters. Excitation and emission filters were as follows: GFP, ex 475/28 nm and em 523/36 nm; CFP, ex $438 / 24 \mathrm{~nm}$ and em $475 / 28 \mathrm{~nm}$; YFP, ex 513/17 $\mathrm{nm}$ and em 548/38 nm. Images were acquired with the softWoRx software 5.5 (Applied Precision) and processed with FIJI (https://fiji.sc/).

\section{Overexpression and purification of FPs from E. coli}

FPs were expressed from the pETHis6TEVLic plasmids in E. coli BL21(DE3) (Additional file 2: Table S2). After $1 \mathrm{mM}$ IPTG induction, cells were grown in LB for $3 \mathrm{~h}\left(37^{\circ} \mathrm{C}, 220 \mathrm{rpm}\right)$. Cells were harvested $\left(6000 \mathrm{~g}, 4{ }^{\circ} \mathrm{C}\right.$, $10 \mathrm{~min}$ ) and washed with buffer A (50 mM Tris $\mathrm{pH}$ 7.6, $50 \mathrm{mM} \mathrm{KCl}, 1 \mathrm{mM}$ DTT, $0.1 \mathrm{mM}$ PMSF, pH 7.4). The cell pellet was resuspended in $10 \mathrm{~mL}$ of lysis buffer $(50 \mathrm{mM}$ $\mathrm{NaH}_{2} \mathrm{PO}_{4}, 300 \mathrm{mM} \mathrm{NaCl}$, and $10 \mathrm{mM}$ imidazole, $\mathrm{pH}$ 7.4, supplemented with oComplete EASYpack EDTA free protease inhibitor). After sonification on ice (10 min, amplitude $75 \%, 15 \mathrm{~s}$ on, $10 \mathrm{~s}$ off), the cell debris was removed by centrifugation $\left(4{ }^{\circ} \mathrm{C}, 50 \mathrm{~min}, 16,200 \mathrm{~g}\right)$ and soluble proteins were purified with a TEV protease-cleavable, N-terminal His6 tag as follows: the supernatant was loaded onto 5-mL Histrap FF columns (GE Healthcare
Life Sciences) and the protein was eluted according to the manufacturer's instruction with an imidazole gradient (solution A: $50 \mathrm{mM} \mathrm{NaH}_{2} \mathrm{PO}_{4}, 300 \mathrm{mM} \mathrm{NaCl}, 10 \mathrm{mM}$ imidazole; solution B: $50 \mathrm{mM} \mathrm{NaH} \mathrm{PO}_{4}, 300 \mathrm{mM} \mathrm{NaCl}$, $500 \mathrm{mM}$ imidazole) using the NGC chromatography system (Bio-Rad).

The N-terminal His6-tag was cleaved off with the TEV protease (ProTEV Plus, Promega) according to manufacturer's instructions. The His6-tag and uncleaved proteins still containing the His6-tag were removed with the HisLink Protein Purification Resin (Promega) according to the manufacturer's protocol. For in vitro characterization of FP properties, proteins were dialyzed against PBS buffer, $\mathrm{pH}$ 7.4, and concentrated using 10kD-cutoff concentrator tubes (Pierce Protein Concentrator PES, Thermo Fisher Scientific). The concentration of purified FP proteins was estimated by measurement at $280 \mathrm{~nm}$ using a Nanodrop spectrophotometer (Thermo Fisher Scientific) and by a Bradford assay with Coomassie G-250 solution (Bio-Rad).

\section{Absorbance and emission spectra of FPs}

To measure the absorbance and emission spectra, the purified FP variants were diluted to $20 \mu \mathrm{g} / \mathrm{mL}$ in a $20 \mathrm{mM}$ Tris-HCl, pH 7.5, $100 \mathrm{mM} \mathrm{NaCl}$ buffer solution. Absorption spectra were recorded between 250 and $600 \mathrm{~nm}$ using $1 \mathrm{~nm}$ step size with a UV-1600 PC spectrophotometer (VWR) at $22{ }^{\circ} \mathrm{C}$. Fluorescence measurements were performed at $22{ }^{\circ} \mathrm{C}$ on a SynergyMX microplate reader (BIOTEK) using white 96-well assay plates (3610, Costar) to which $75 \mu \mathrm{L}$ per well was added. Emission spectra were measured between 300 and $700 \mathrm{~nm}$ with a $1 \mathrm{~nm}$ step size by exciting at 444 or $485 \mathrm{~nm}$, respectively.

\section{In vitro thermal stability of FPs}

FPs were diluted to $20 \mu \mathrm{g} / \mathrm{mL}$ in $50 \mu \mathrm{L}$ of TNG buffer (100 mM Tris, pH 7.5, $100 \mathrm{mM} \mathrm{NaCl}, 10 \%$ glycerol) into 96-well PCR plates (iCycler IQ, Bio-Rad). Denaturation was monitored in a 7300 real-time PCR system (Applied Biosystems) at $488 \mathrm{~nm}$ excitation and $530 \mathrm{~nm}$ emission (FAM filter). The unfolding profile was resolved between 20 and $99{ }^{\circ} \mathrm{C}$ with a $30 \mathrm{~s} /{ }^{\circ} \mathrm{C}$ stepwise increase of the temperature.

\section{Results \\ Benchmarking GFP performance in $P$. thermoglucosidasius DSM 2542}

To identify the most suitable GFP candidate for subsequent randomized mutagenesis and in vivo selection of temperature-stable mutants, we initially compared the expression of seven GFPs. These had been previously optimized for improved brightness, solubility, folding kinetics or were codon optimized for the application 
in different bacterial expression hosts (Table 2). The FP genes were inserted into the multiple cloning site of a derivative of the E. coli-Bacillus shuttle vector pNW33N (Additional file 2), thereby enabling a constitutive expression from the promoter of the $P$. thermoglucosidasiusderived housekeeping gene phosphate acetyltransferase (pta). The plasmid map is shown in Additional file 3. The transformed $P$. thermoglucosidasius DSM 2542 strains were grown at a moderate temperature of $53{ }^{\circ} \mathrm{C}$ in TGP broth and the distribution of fluorescence intensities of individual cells was evaluated from early logarithmic to late stationary phase using flow cytometry (exemplified in Additional file 3: Figure S1 B-D). We generally observed two trends: (i) cells transformed with less engineered GFP variants that are closely related to the originally isolated sequence of the A. victoria GFP showed either none or only marginal fluorescence above the autofluorescence background of $P$. thermoglucosidasius wild-type cells and (ii) cells transformed with sfGFP variants produced a detectable fluorescence signal (Fig. 1a). However, the signal intensities varied considerably amongst the sfGFP types, which differ in their nucleotide sequence, but not in their amino acid sequence (Table 2). The most surprising aspect was that a sfGFP variant, which had been codon optimized for expression in the closely related species Geobacillus stearothermophilus [40], gave very low detectable signals in the DSM 2542 background (Additional file 3: Figure S1 D). The sfGFP gene optimized for expression in Streptococcus pneumonia $[\mathrm{sfGFP}(\mathrm{Sp})]$, on the contrary, exhibited the highest mean fluorescence intensity (MFI) at $53{ }^{\circ} \mathrm{C}$ (Fig. 1a). When the strain was grown at the optimal growth temperature of $60{ }^{\circ} \mathrm{C}$, the mean fluorescence decreased by $95 \%$ thereby indicating that $\operatorname{sfGFP}(\mathrm{Sp})$ was not functionally expressed, degraded or misfolded in a the majority of the cells (Fig. 1b). We, therefore, used the $\operatorname{sfGFP}(\mathrm{Sp})$ gene as starting material for an undirected mutagenesis approach to select the best performing mutants by in vivo screening.

\section{In vivo isolation of thermostable sfGFP variants}

In an undirected, error-prone PCR approach, we randomly mutagenized the $\operatorname{sfGFP}(\mathrm{Sp})$ gene, thereby achieving a DNA library of 45,000 variants in $E$. coli with an average mutation rate of 2.8 exchanges per $\mathrm{kb}$, which corresponds to an average of one to five amino acid exchanges per protein. After re-isolation from E. coli, the plasmid library was transformed into DSM 2542, which yielded a final library of $\sim 6000$ clones. Following four rounds of subsequent FACS enrichment of cells that produced the highest GFP emission signals at 55,60 or $65{ }^{\circ} \mathrm{C}$, respectively, (Additional file 4: Figure S2 A, B), the fluorescence intensity of 120 of the brightest individual colonies recovered on TGP plates was subsequently measured by flow cytometry (Additional file 4: Figure S2 C). Fifty variants showing the highest improvement in mean fluorescence intensity, in combination with the least cell-to-cell variation of GFP signal intensities, were further analyzed by sequencing. All variants were untruncated and contained a range of one to seven nucleotide substitutions per gene. Examples of sequences of isolated protein are provided in Additional file 5 . Among the 20 mutations that were found in the 50 sequenced proteins, different trends could be observed: eight occurred in the flexible loop regions that connect the $\beta$-strands or constitute the lid of the $\beta$-barrel (Fig. 2). Other thermostability-promoting substitutions were found to be preferentially located in the $\mathrm{N}$ terminus and the first beta-strand. Four exchanges were synonymous,
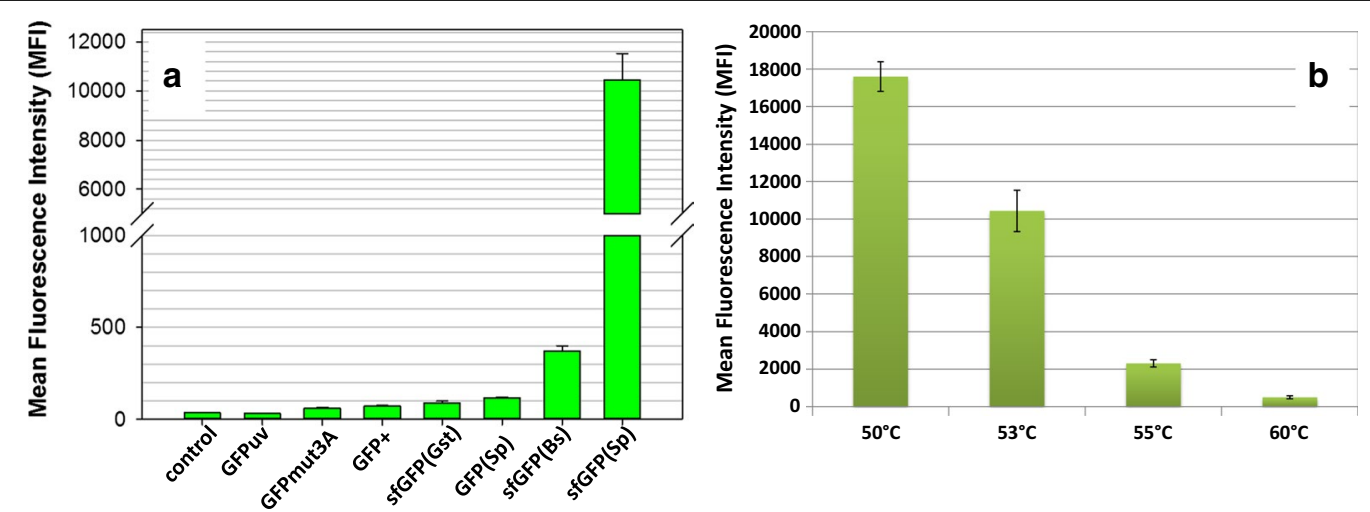

Fig. 1 Benchmarking of GFP expression in P. thermoglucosidasius DSM 2542. a Expression of different GFP variants from pNW-Ppta-GFPx-3TER plasmids at $53{ }^{\circ} \mathrm{C}$ in TGP broth was analyzed by flow cytometry at the mid-exponential phase of growth. The mean fluorescence intensity (MFI) of 50,000 cells is shown. Control, autofluorescence of DSM 2542 containing a pNW-Ppta-3TER plasmids without gfp gene (b). Temperature-dependent performance of sfGFP(Sp) as assessed flow cytometry. The MFI of 50,000 cells at the mid-exponential phase of growth cells grown at indicated temperatures in TGP broth is presented. The averages of three biological triplicates are shown with error bars indicating standard deviations 


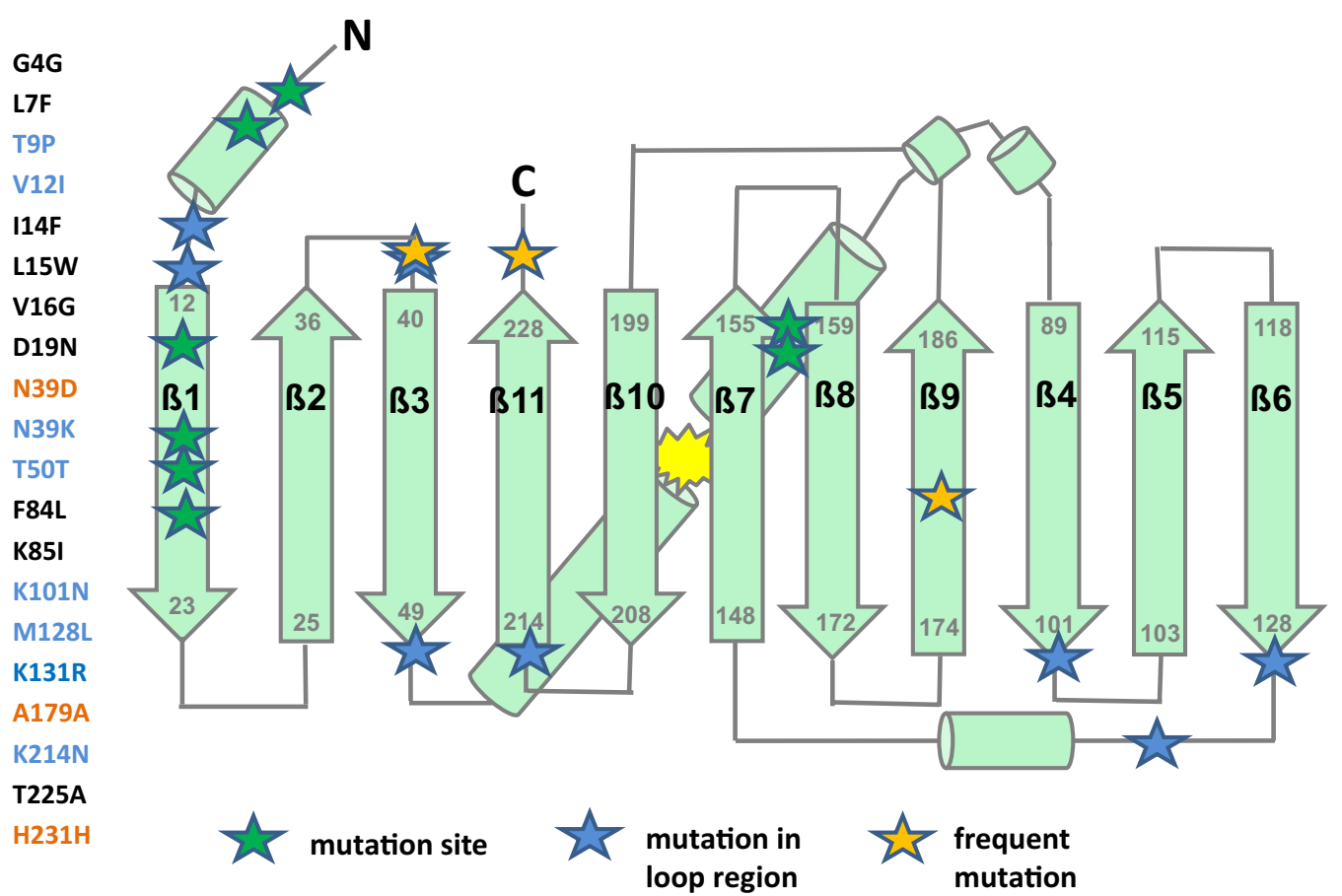

Fig. 2 Topology map of sfGFP with thermostability-enhancing mutations isolated from in vivo FACS screening of DSM 2542. Left side: mutations found in the 50 sequenced mutants obtained by cell sorting from the sfGFP(Sp) library. Green stars: mutations found in at least 1 out of 50 protein sequences; blue stars: mutations that map to loop sites or flexible linker regions; orange stars: mutations that occurred in more than 10 out of 50 sfGFP(Sp) variants. Yellow cloud: chromophore

thereby leaving the amino acid sequence unchanged. Interestingly, A179A and $\mathrm{H} 231 \mathrm{H}$ were reoccurring substitutions and accounted for 24 out of 50 and 10 out of 50 sequences, respectively. Moreover, these silent mutations replaced less favorable codons with codons that are more frequently used in $P$. thermoglucosidasius, with a ratio of 1.2 for A179A (GCT $\rightarrow$ GCC) and a ratio of 3.1 for $\mathrm{H} 231 \mathrm{H}$ $(\mathrm{CAC} \rightarrow \mathrm{CAT})$. An additional reoccurring mutation was the N39D variation found in 24 out of 50 variants.

\section{Characterization of the in vivo thermostability of mutant sfGFP(N39D/A179A)}

Next, we analyzed one mutant displaying highly improved properties that contained two of the most frequently occurring mutations, N39D and A179A, in more detail (Table 3; Additional file 5). After re-cloning of $\operatorname{sfGFP}(\mathrm{N} 39 \mathrm{D} / \mathrm{A} 179 \mathrm{~A})$ into $\mathrm{pNW}-\mathrm{P}_{\mathrm{pta}}-3 \mathrm{TER}$ and retransformation into DSM 2542, this mutant still showed improved brightness compared to the parental sfGFP(Sp) reporter, indicating that the $\mathrm{N} 39 \mathrm{D}$ and $\mathrm{A} 179 \mathrm{~A}$ mutations are crucial substitutions that affect its performance. The enhanced in vivo thermotolerance was further proven when the cells were subjected to increased temperatures (Fig. 3). In comparison to the original protein $\mathrm{sfGFP}(\mathrm{Sp})$, the MFI was increased 885-fold to 53,050 MFI at the optimal growth temperature of $60{ }^{\circ} \mathrm{C}$. While exhibiting very high fluorescence signals at $55{ }^{\circ} \mathrm{C}$ that were at the detection limit for the flow cytometer (MFI of $>60,000$ ), the variant lost activity at $65{ }^{\circ} \mathrm{C}(\mathrm{MFI}=8075)$ and displayed a broader heterogeneity in distribution of the signal intensity between single cells. Since $65^{\circ} \mathrm{C}$ exceeds the optimum growth temperature and reflects a stress condition for DSM 2542, we hypothesized that the thermal stress might lead to a reduced folding efficiency or partial unfolding of $\operatorname{sfGFP}(\mathrm{N} 39 \mathrm{D} / \mathrm{A} 179 \mathrm{~A})$ proteins in a fraction of the cells.

\section{Combination of the most frequently occurring thermostabilizing mutations does not lead to further improvement}

We next opted to study whether the combination of all three most frequently occurring mutations, N39D, A179A and H231H (Fig. 2; Table 3), would lead to synergistic effects in terms of improving the thermostability of the protein. The silent $\mathrm{H} 231 \mathrm{H}$ mutation $(\mathrm{CAC} \rightarrow \mathrm{CAT})$ was introduced via site-directed mutagenesis PCR into the sfGFP(N39D/A179A) variant. The resulting mutant, termed sfGFP(N39D/A179A/H231H), was expressed from $\mathrm{pNW}-\mathrm{P}_{\mathrm{pta}^{-}}$-sfGFP(N39D/A179A/H231H)-3TER in DSM 2452 under the same conditions as stated above. We 


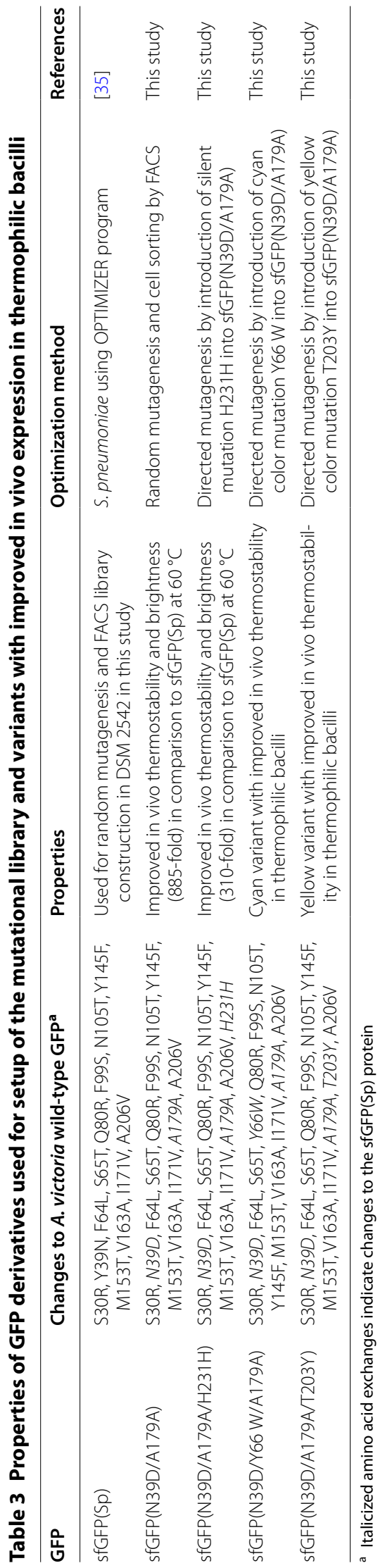




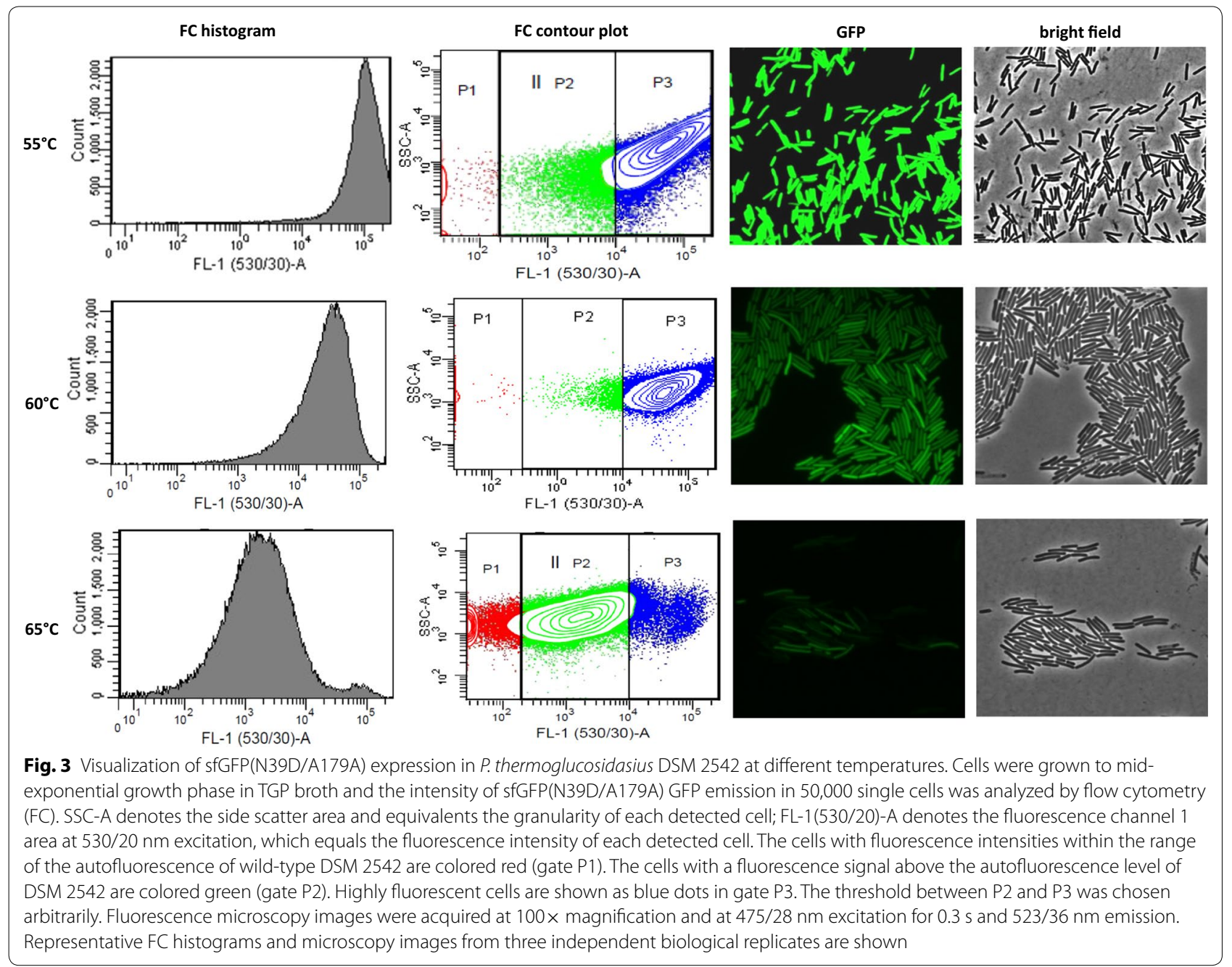

additionally subcloned the sfGFP(iGEM) gene (Table 2), because its functional, although temperature-dependent expression in a Geobacillus strain had meanwhile been reported [22]. Comparison of signal intensities from cells grown at $60{ }^{\circ} \mathrm{C}$ revealed that i) the combination of thermostability-enhancing mutations led to reduced fluorescence of the $\operatorname{sfGFP}(\mathrm{N} 39 \mathrm{D} / \mathrm{A} 179 \mathrm{~A} / \mathrm{H} 231 \mathrm{H})$ variant and ii) next to reduced signal intensities, the sfGFP(iGEM) variant showed an extremely broad dynamic range when comparing the signal intensity derived from single cells. This indicates that this variant is not equally well expressed and/or folded at $60^{\circ} \mathrm{C}$, thus making it less suitable as a promoter output element in P. thermoglucosidasius DSM 2542 (Fig. 4a).

The effect was becoming more pronounced when the mean fluorescence intensities of the original protein, sfGFP(Sp), its derivatives sfGFP(N39D/A179A) and $\operatorname{sfGFP}(\mathrm{N} 39 \mathrm{D} / \mathrm{A} 179 \mathrm{~A} / \mathrm{H} 231 \mathrm{H})$ and the $\operatorname{sfGFP}(\mathrm{iGEM})$ variant were compared at 55,60 and $65{ }^{\circ} \mathrm{C}$, respectively
(Fig. 4b). We, therefore, concluded that the nucleotide sequence and thus the codon usage must play an important role in conferring functional expression in dependence on the temperature. Additionally, the N39D amino acid exchange seems to further optimize the expression and/or the folding at higher temperatures, making it the most reliable variant with respect to cell-to-cell variation and signal intensity for (Para)geobacilli reported so far.

\section{In vivo functionality of sfGFP(N39D/A179A) in different host backgrounds}

Since there is a limited number of reports on the usage of GFP reporters in thermophilic spore formers, we next tested the applicability of the improved $\operatorname{sfGFP}(\mathrm{N} 39 \mathrm{D} /$ A179A) variant in a set of (moderately) thermophilic Bacillus and (Para)geobacillus strains, which are currently in the focus of establishment and expansion as industrial platform organisms (Table 1). Although the expression of the thermostable $\operatorname{sfGFP}(\mathrm{N} 39 \mathrm{D} / \mathrm{A} 179 \mathrm{~A})$ 

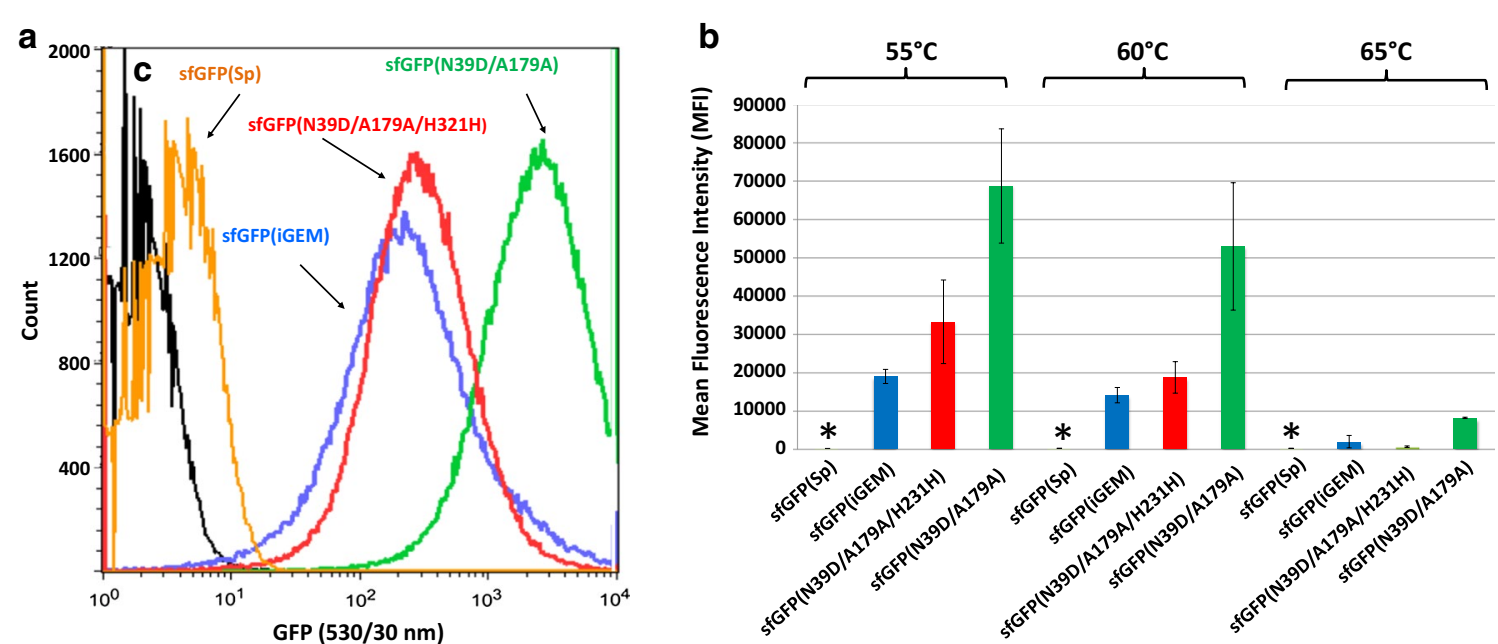

Fig. 4 Influence of synonymous amino acid substitutions and N39D replacement on the in vivo performance of sfGFP in P. thermoglucosidasius. a Flow cytometry-based comparison of the signal intensities of mid-log DSM 2542 cells transformed with sfGFP(Sp), orange; sfGFP(iGEM), blue; sfGFP(N39D, A179A, H231H), red; sfGFP(N39D/A179A) (green) grown at $60^{\circ} \mathrm{C}$ in TGP broth. C, control cells containing the pNW-Ppta-3TER plasmid without gfp gene (black). Representative histograms of three independent biological replicates are shown. $\mathbf{b}$ Analysis of temperature-dependent functionality of the four sfGFP variants at mid-exponential growth phase in DSM 2542 as assessed by flow cytometry. The MFI is presented in relative fluorescence units (R.F.U.) and is the average of three independent biological replicates with error bars showing standard deviations. Asterisks denote the detection of fluorescence signals marginally above the autofluorescence of mock cells as shown in control (c) in a

protein was driven by the $P$. thermoglucosidasius-derived constitutively active pta promoter from the plasmid pNW-P pta $^{-}$-sfGFP(N39D7A179A-3TER), all tested strains functionally expressed the reporter protein, as visualized by fluorescence microscopy (Fig. 5). This underpins that despite of deviating codon usage in these organisms, the in vivo-selected mutations confer an advantage for a reliable expression of our in vivo-isolated reporter protein at thermophilic temperatures.

\section{In vivo functionality of sfGFP(N39D/A179A) cyan and yellow derivatives in different host backgrounds} For dual- or multi-labeling strategies, it would be desirable to have additional spectral FP variants that are thermostable. We thus introduced the mutations Y66W or T203Y that had previously been described to lead to cyan and yellow fluorescent color variants of GFP, respectively $[45,46]$ into sfGFP(N39D/A179A). The gene was mutated by site-directed mutagenesis PCR and the resulting $\operatorname{sfCFP}(\mathrm{N} 39 \mathrm{D} / \mathrm{A} 179 \mathrm{~A})$ and $\mathrm{sfYFP}(\mathrm{N} 39 \mathrm{D} / \mathrm{A} 179 \mathrm{~A})$ amplicons were cloned into the $\mathrm{pNW}-\mathrm{P}_{\mathrm{pta}}-3 \mathrm{TER}$ plasmid. To analyze whether the newly introduced nucleotide exchanges impact the expression of the proteins in vivo, the plasmids were transformed into $P$. thermoglucosidasius DSM 2542 and into additional Bacillus and Geobacillus type strains and the expression was monitored by fluorescence microscopy (Fig. 6). A clearly detectable fluorescence signal illustrates that the applicability of the cyan and yellow color derivatives of sfGFP(N39D/
A179A) was not restricted to $P$. thermoglucosidasius. While sfCFP(N39D/A179A and sfYFPS(N39D/A179A) were also functionally expressed in B. smithii, B. coagulans and G. thermodenitrificans, we were repeatedly unable to obtain transformants of $B$. methanolicus because of their low transformation efficiency. However, since we did not test the expression strength of the pta promoter in these hosts, it might be possible that stronger and/or species-specific promoters and plasmid backbones would lead to detectable fluorescence. The same applies to the detection of yellow fluorescence in B. coagulans DSM 1, which might be increased above the level of cellular autofluorescence when a stronger promoter would be used to drive sfYFP expression.

\section{In vitro properties of sfGFP(N39D/A179A) and its cyan and yellow derivatives}

To gain insight into the reason of the improved performance of $\operatorname{sfGFP}(\mathrm{N} 39 \mathrm{D} / \mathrm{A} 179 \mathrm{~A})$ and its derivatives as compared to the original sfGFP(Sp) protein, we analyzed the thermal in vitro stabilities and the spectral properties (Fig. 7). After amplification with the primer pair LICv1sfGFP_Fs and LICv1sfGFP_Rev, genes were cloned into the expression vector pETHis6TEVLic (1B) and transferred to $E$. coli BL21(DE3) for IPTG-induced expression. After affinity purification and removal of the N-terminal His6tag, the $\operatorname{sfGFP}(\mathrm{Sp})$ and $\operatorname{sfGFP}(\mathrm{N} 39 \mathrm{D} / \mathrm{A} 179 \mathrm{~A})$ proteins showed similar excitation and emission spectra with an absorbance peak at $486 \mathrm{~nm}$ and an emission maximum 

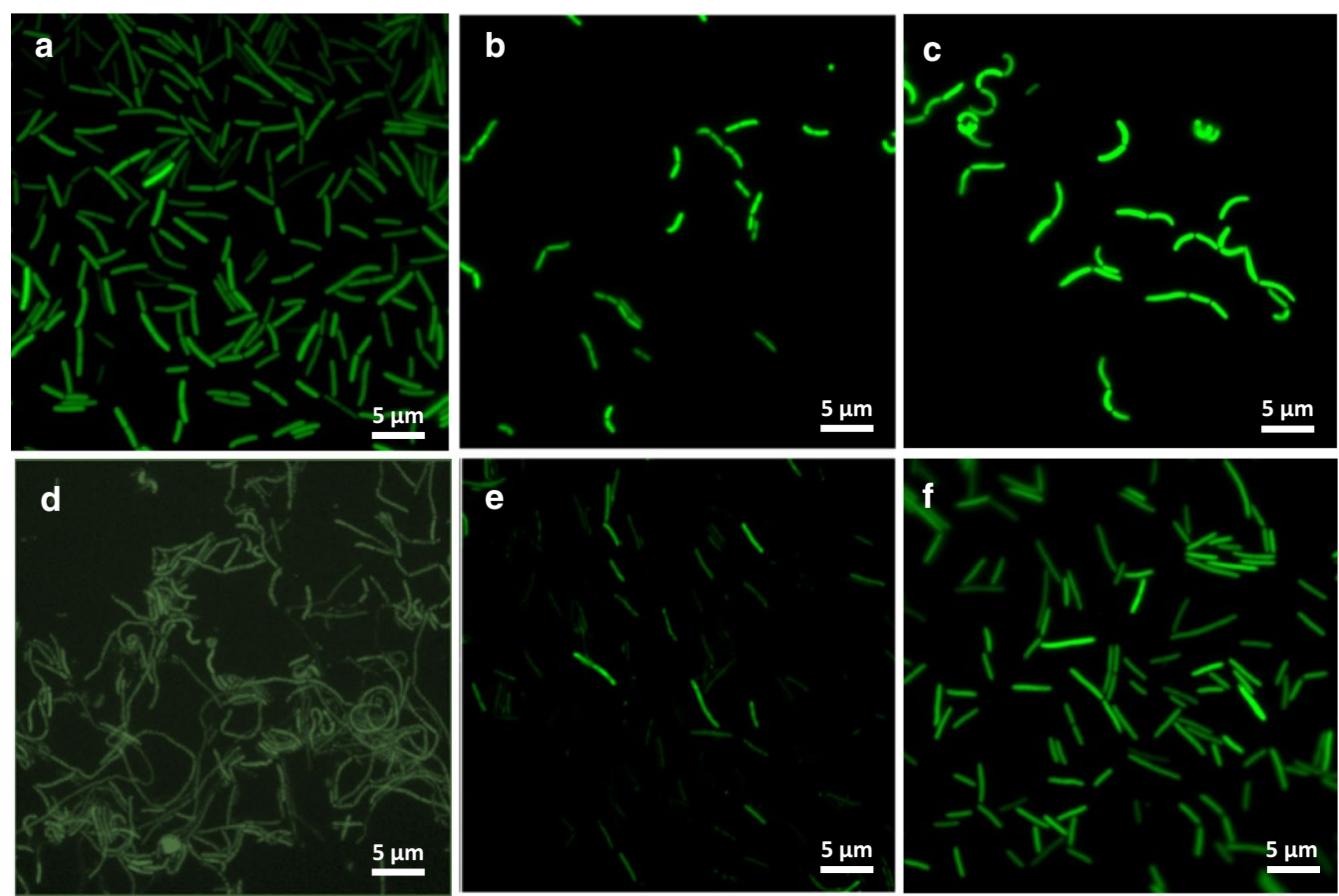

Fig. 5 Visualization of sfGFP(N39D/A179A) expression in different thermophilic spore-forming species by fluorescence microscopy. Expression of the thermostable GFP variant sfGFP(N39D/A179A) from the plasmid pNW-Ppta-sfGFP(N39D/A179A)-3TER was imaged after growing the transformed strains on growth media as specified in "Methods". a P. thermoglucosidasius DSM $2542\left(60^{\circ} \mathrm{C}\right), \mathbf{b}$ B. smithii DSM $4216\left(55^{\circ} \mathrm{C}\right), \mathbf{c} B . \operatorname{coagulans}$ $\operatorname{DSM} 1\left(50^{\circ} \mathrm{C}\right), \mathbf{d}$ B. methanolicus DSM $16454\left(60^{\circ} \mathrm{C}\right), \mathbf{e} \mathrm{G}$. thermodenitrificans DSM $465\left(60^{\circ} \mathrm{C}\right), \mathbf{f} \mathrm{G}$. thermodenitrificans $\mathrm{T} 12\left(60^{\circ} \mathrm{C}\right)$. Excitation time, excitation and emission wavelengths and filter settings are given in "Methods"

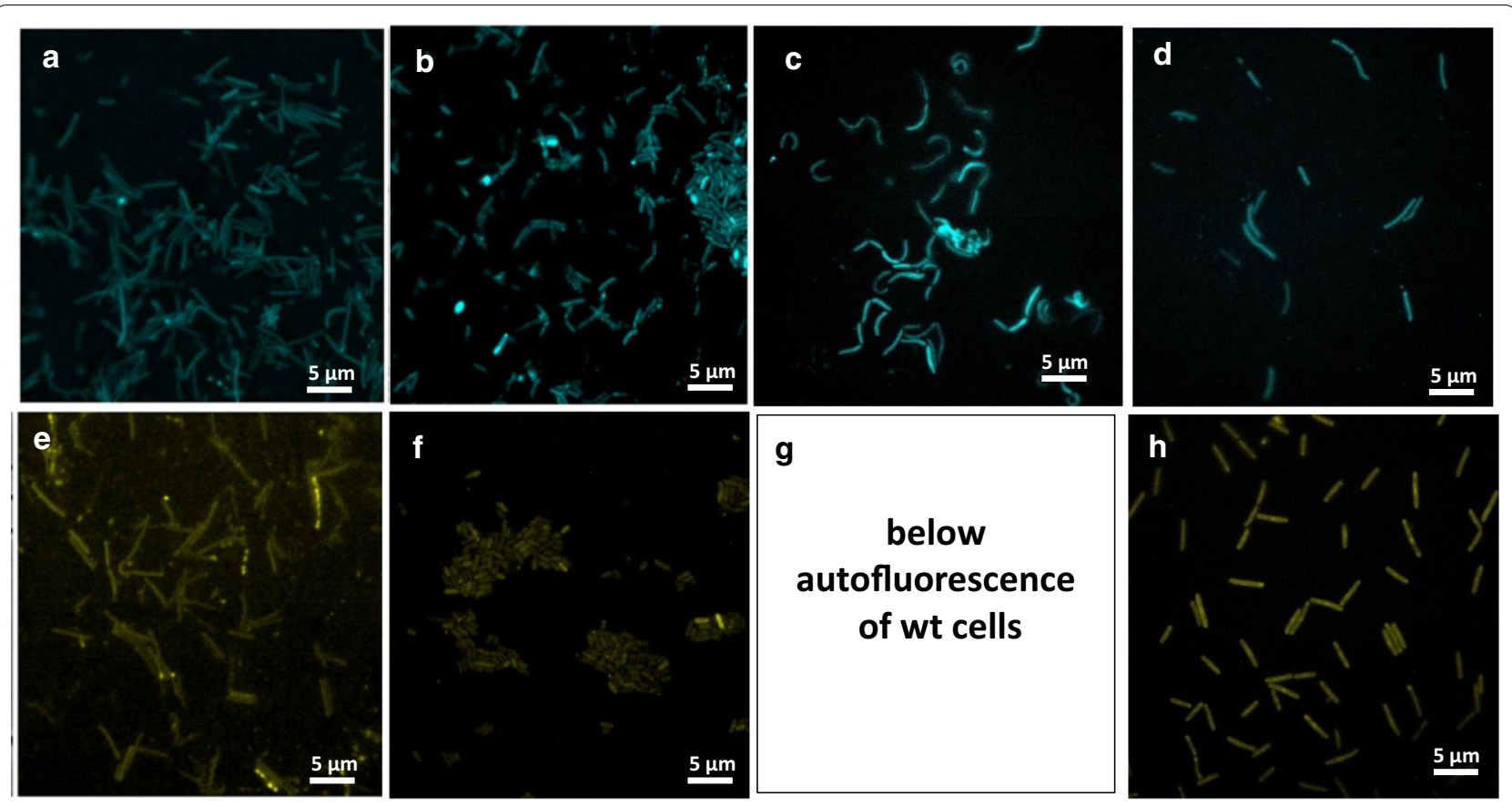

Fig. 6 Visualization of expression of FP color variants in different (moderate) thermophilic spore-forming species. Expression of the cyan variant sfCFP(N39D/A179A) and the yellow variant sfYFP(N39D/A179A) from the corresponding pNW-P pta $^{-G F P x-3 T E R ~ p l a s m i d s ~ w a s ~ m o n i t o r e d ~ a f t e r ~ g r o w-~}$ ing the transformed strains at their indicated optimal growth temperatures. $\mathbf{a}$, e P. thermoglucosidasius DSM $2542\left(60^{\circ} \mathrm{C}\right), \mathbf{b}, \mathbf{f} B . \operatorname{smithii~DSM} 4216$ $\left(55^{\circ} \mathrm{C}\right), \mathbf{c}, \mathbf{g}$ B. coagulans DSM $1\left(50^{\circ} \mathrm{C}\right), \mathbf{d}, \mathbf{h}$ G. thermodenitrificans $T 12\left(60^{\circ} \mathrm{C}\right)$. For excitation time, excitation and emission wavelengths and filter settings see "Methods" 

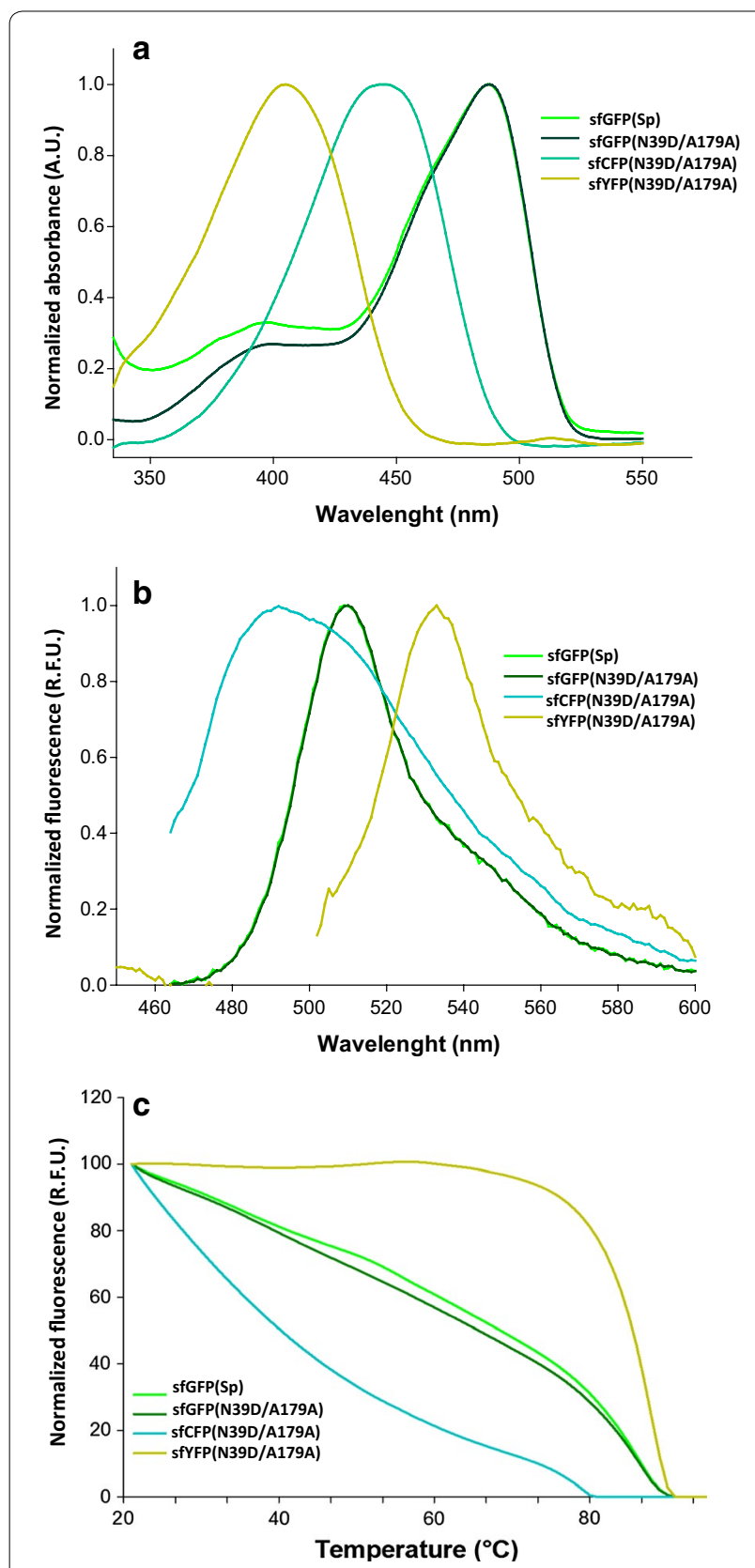

Fig. 7 Spectral properties and thermal stability of in vivo-selected sfGFPS102 and its color derivatives compared to the sfGFP(Sp) protein. a Absorbance spectra were recorded between 250 and $600 \mathrm{~nm}$ using a 1-nm step size in the spectrometer and were normalized to 1 for the respective maximum peaks. A.U., absorbance units. b Fluorescence spectra recorded at an excitation wavelength of $485 \mathrm{~nm}$ for sfGFPS102, sfGFP(Sp), sfGFPYFPS102 and at $444 \mathrm{~nm}$ for sfCFPS102. Curves were normalized to 1 for the respective maximum peak. R.F.U. relative fluorescence units. c Thermal stability was determined by measuring the emission at $530 \mathrm{~nm}$ with an excitation of $488 \mathrm{~nm}$ while proteins were subjected to heat in steps of $30 \mathrm{~s} / 1^{\circ} \mathrm{C}$ from 20 to $99^{\circ} \mathrm{C}$. R.F.U. relative fluorescence units at $510 \mathrm{~nm}$. The cyan variant sfCFPS102 was blue shifted with an absorbance peak at $444 \mathrm{~nm}$ and maximum emission at $491 \mathrm{~nm}$. The yellow variant sfYFPS102 showed a bimodal absorbance spectrum corresponding to the protonated and anionic state, with a major peak at $405 \mathrm{~nm}$ and a minor peak at $512 \mathrm{~nm}$, while the maximum emission was detected at $524 \mathrm{~nm}$. Remarkably, there was no significant difference in the in vitro thermal stability of sfGFP(N39D/ $\mathrm{A} 179 \mathrm{~A})$ and its parental protein $\mathrm{sfGFP}(\mathrm{Sp})($ Fig. 7c). While the cyan variant of S102 lost its activity more rapidly during thermal treatment, the introduction of the T203Y mutation in the yellow S102 derivative seemed to stabilize fluorescence emission at higher temperatures.

\section{Discussion}

Gram-positive, thermophilic bacteria of the genera Parageobacillus and Geobacillus are relevant for biotechnological applications and metabolic engineering for the production of green chemicals from renewable resources such as plant biomass $[19,47]$. In this work, we developed a thermostable fluorescent reporter protein, chosen out of several good candidates, that provides a reliable optical readout enabling the quantification of promoter activity changes in single cells or cell populations at $60^{\circ} \mathrm{C}$. We had to overcome two general limitations associated with in vivo functionality of FPs: their strong performance dependence on the host background and temperature dependence of the robustness of folding.

The initial benchmarking of a set of FPs showed that superfolder GFP (sfGFP) proteins were better detectable in $P$. thermoglucosidasius DSM 2542 than the less engineered GFP proteins at $53{ }^{\circ} \mathrm{C}$ (Fig. 1a). Given that sfGFP folds an order of magnitude faster than GFP [48], it seems plausible that its folding-accelerating mutations support the functionality at higher temperatures [38]. Since thermal stress of a protein above a certain critical temperature usually leads to improper protein folding and rapid aggregation $[49,50]$, and can profoundly decrease the maturation efficiency of GFPs [29], it can be speculated that the possibility of occurrence of aggregation-prone or misfolded intermediates is reduced for sfGFPs at elevated temperatures. It has been proposed earlier that faster folding rates within cells allow for greater total fluorescence, because more rapidly folded proteins are protected from degradation and are capable of forming the chromophore [51].

We further observed that sfGFP variants identical at the amino acid level, which were codon-optimized for G. stearothermophilus or B. subtilis, gave lower fluorescence signals than a variant optimized for S. pneumoniae 
(Fig. 1a and Table 2). This illustrates that the codon usage bias strongly affects the performance of sfGFP variants in $P$. thermoglucosidasius. Similar findings have been reported previously: Although the FP genes were transcribed, the codon usage bias either leads to low levels of translation [52-54], and/or improper folding and loss of functionality, especially at higher temperatures [55]. Thus, codon optimization, a method that introduces favorable and more frequent codons as silent mutations that do not change the primary protein sequence, has been shown to positively influence protein synthesis and lower the rate of mistranslations in cases of some proteins $[53,56,57]$. On the contrary, codon optimization did not yield higher fluorescence or protein expression in other studies $[35,58,59]$, indicating that a functional expression depends on a more complex synergy of factors. Although GFP protein levels from a synthetic library of genes that differ randomly at synonymous sites varied 250-fold when expressed in E. coli, the codon bias did not correlate with gene expression. GFP levels were rather associated with stability of mRNA folding near the ribosomal binding site, mRNA levels and mRNA degradation patterns [60]. Other factors that might also affect sfGFP expression could be associated with mRNA:ncRNA interactions, tRNA abundance, co-translational folding, the translation rhythm, speed of folding and the macromolecular crowding [61-68].

This underpins that rational engineering by codon optimization algorithms does not always result in improved heterologous gene expression and protein functionality and that in vivo screening approaches might in some cases be better suited to isolate thermostable FP proteins. This is in line with a recently published in vivo selection method called Hot-CoFi, which was demonstrated for successful identification of thermostability-enhancing mutations in a set of proteins [69]. Similarly, our in vivo screen after random mutagenesis of $\operatorname{sfGFP}(\mathrm{Sp})$ allowed a direct selection of heat-stable sfGFP variants by instantly omitting mutants with compromised activity (Fig. 2 and Additional file 4: Figure S2).

In general, the amino acid replacements enhanced the hydrophobicity of the proteins by introducing larger hydrophobic residues and exchanged positive or negative charges with polar uncharged or hydrophobic amino acids, respectively. This is in agreement with studies that addressed the differences between mesophilic and thermophilic protein compositions, showing that the hydrophobic content of amino acids is higher in thermophilic proteins [70, 71]. Additionally, a lower overall hydrophobicity leads to diminished tendency to aggregate, as has been shown for GFPuv [72]. We, furthermore, observed an enrichment of mutations in the $\mathrm{N}$ terminus and the first beta-strand of sfGFP as well as in the flexible loops and linker regions that connect the $\beta$-strands (Fig. 2). Interestingly, similar hotspots, in which stabilizing mutations are clustered in particular regions of proteins, have also been reported to occur in an in vitro screen for enhanced thermostable proteins [69]. The thermostabilizing effect of mutations located on turns of n-caps of helices has been attributed to the reduction of conformational entropy thus enhancing entropic stabilization at higher temperatures $[73,74]$. These factors might explain the in vivo FACS selection of these specific mutants; however, much more detailed studies are necessary to judge the impact on folding and maturation of sfGFP of the specific amino acid substitutions and are beyond the scope of this study.

The N39D mutation and the replacement of slow- to fast-translated codons in A179A and $\mathrm{H} 231 \mathrm{H}$ (Additional file 5) occurred with higher frequency in the in vivoisolated proteins, thus indicating that these are indeed crucial substitutions affecting the fluorescence readouts. Especially the combination of N39D and A179A in the mutant sfGFP(N39D/A179A) provided the greatest improvement in in vivo functionality in the DSM 2542 background grown at $60{ }^{\circ} \mathrm{C}$ : small signal amplitude with respect to cell-to-cell variation and comparably high fluorescence intensity, which was 885 -fold increased in contrast to the original sfGFP $(\mathrm{Sp})$ protein at $60{ }^{\circ} \mathrm{C}$ (Figs. 3, 4). However, neither the excitation and emission spectra nor the in vitro temperature stability of $\operatorname{sfGFP}(\mathrm{N} 39 \mathrm{D} /$ $\mathrm{A} 179 \mathrm{~A})$ was altered in comparison to the $\mathrm{sfGFP}(\mathrm{Sp})$ protein (Fig. 7). Furthermore, the recombination of all three frequent mutations in the $\operatorname{sfGFP}(\mathrm{N} 39 \mathrm{D} / \mathrm{A} 179 \mathrm{~A} / \mathrm{H} 231 \mathrm{H})$ mutant protein impaired its thermal in vivo performance (Fig. 4). This is in good agreement with the findings from the GFP benchmarking (Fig. 1a), indicating that the nucleotide sequence and the codon usage is of high importance for the performance of reporter proteins in this host.

The findings further strongly suggest that a combination of an altered tertiary structure (N39D) and altered translation speed due to a different codon usage frequency (A179A) causes an increase in fluorescence at $60{ }^{\circ} \mathrm{C}$ of the sfGFP(N39D/A179A) mutant. In line with this, it has been concluded earlier that differences in the amino acid composition are not the only thermostability modulating factors and that synonymous mutations impact the translation speed of proteins [73]. Additionally, it had been shown that an extrinsic selective force for gene mutations in thermophiles was particularly linked to the process of synonymous codon usage for arginine and isoleucine [71]. It is a generally accepted view that silent substitutions alter the translation elongation rates and efficiencies of protein folding [75-78]. Thus, in the case of the A179A mutation, the replacement of a slow (rare) 
with a fast (frequent) arginine codon might enhance the translation speed of the protein variant and accelerate its maturation, which might confer protection against degradation of misfolded or incompletely folded intermediates. Interestingly, the N39D mutation removed asparagine, which is considered a thermolabile amino acid [73]. Moreover, the N39D replacement reversed the original superfolder mutation $\mathrm{Y} 39 \mathrm{~N}$, which was shown to initiate the formation of an alpha-helix at the loop between the second and third beta-strands of the barrel and contributed to the folding robustness by stabilizing this protein region [38]. It would thus be interesting to perform crystallization studies of sfGFP(N39D/A179A), to shed light on the contribution of 39D to the in vivo thermostability of the protein. Thus, current studies are underway to determine whether the translation rate, mRNA or protein decay contribute to the improved in vivo functionality of sfGFP(N39D/A179A) in P. thermoglucosidasius.

Based on previously reported mutations shifting the spectral properties of GFP $[45,46]$, we constructed cyan and yellow color derivatives of $\operatorname{sfGFP}(\mathrm{N} 39 \mathrm{D} / \mathrm{A} 179 \mathrm{~A})$. These variants showed the expected modifications in excitation and emission spectra in vitro (Fig. 7a, b) and could be detected in in vivo expression experiments in P. thermoglucosidasius (Fig. 6). To our knowledge, this is the first report of sfCFP and sfYFP proteins being successfully expressed in thermophilic spore-forming bacteria in vivo. Both variants displayed altered thermostability profiles compared to the $\operatorname{sfGFP}(\mathrm{N} 39 \mathrm{D} / \mathrm{A} 179 \mathrm{~A})$ protein (Fig. 7c), indicating that the introduced amino acid substitutions impact the in vitro unfolding kinetics. This is presumably based on noncovalent interactions of the altered chromophore region with the $\beta$-barrel that influence the protein stability [30], and on differences in vibrational disruption of the local fluorophore environment [79], which has been reported to be much more stable due to extended pi-pi stacking interactions of 203Y with the chromophore in the yellow exciting FP [46].

Since the in vivo-applicability of sfGFP(N39D/A179A), $\operatorname{sfCFP}(\mathrm{N} 39 \mathrm{D} / \mathrm{A} 179 \mathrm{~A})$ and $\mathrm{sfYFP}(\mathrm{N} 39 \mathrm{D} / \mathrm{A} 179 \mathrm{~A})$ was proven in a set of additional industrially relevant (moderately) thermophilic bacteria (Figs. 5, 6), we expect that this set of proteins has numerous applications for industrial, as well as basic research questions in these organisms. For instance, it might be possible to use sfGFP(N39D/A179A) as a folding reporter, similar to the original sfGFP, to screen for correctly folded proteins such as biotechnologically relevant enzymes when expressed at high temperatures.

\section{Conclusions}

We demonstrated that a combination of random undirected mutagenesis of the GFP gene with in vivo isolation of the best performing clones by fluorescence-assisted cell sorting turned out to be a powerful strategy to isolate well-expressed variants with significantly improved thermostability in thermophilic bacteria.

We present a mutant of sfGFP, termed sfGFP(N39D/ A179A), which is 885 -fold brighter than the benchmarked parental protein $\operatorname{sfGFP}(\mathrm{Sp})$ and active in $P$. thermoglucosidasius as well as in B. smithii, B. coagulans, $B$. methanolicus and G. thermodenitrificans grown between 45 and $65{ }^{\circ} \mathrm{C}$. This demonstrates its broad applicability in diverse thermophilic bacteria of biotechnological relevance. $\operatorname{sfGFP}(\mathrm{N} 39 \mathrm{D} / \mathrm{A} 179 \mathrm{~A})$ and its cyan and yellow color derivatives are thus of interest for a variety of applications in metabolic and cellular engineering. In contrast to previously published sfGFP or GFP variants, whose thermostability or functionality in $P$. thermoglucosidasius was either not proven in vivo or not assessed at the single-cell level, sfGFP(N39D/A179A) shows a comparably narrow signal amplitude and an extreme brightness in single cells. This is important to perform meaningful quantification of weak, strong, and inducible promoter activity changes at the single cell and at the population level.

The novel variants can be applied for the determination of promoter and RBS strengths, to monitor metabolite conversions or fluxes and for in situ localization of proteins in the cellular environment. Therefore, it is now possible to perform real-time monitoring of biological processes in thermophilic bacteria that are of industrial and biotechnological interest.

\section{Additional files}

Additional file 1. Oligonucleotides designed and used in this study.

Additional file 2. Plasmids used in this study.

Additional file 3. Plasmid map of pNW-P pta -GFPX-3TER and examples of expression kinetics of different GFP types in P. thermoglucosidasius.

Additional file 4. Workflow for in vivo enrichment of thermostable sfGFP mutants and single variant screening in $P$. thermog/ucosidasius.

Additional file 5. Table listing examples of thermostable sfGFP variants isolated from FACS enrichment in P. thermoglucosidasius DSM 2542 at $60^{\circ} \mathrm{C}$

\section{Abbreviations}

FP: fluorescent protein; GFP: green fluorescent protein; sfGFP: superfolder green fluorescent protein; CFP: cyan fluorescent protein; YFP: yellow fluorescent protein; ex: excitation; em: emission. 


\section{Authors' contributions}

EF designed, executed and analyzed the experiments and wrote the manuscript. OPK and RvK initiated the project and participated in the design and co-ordination of the study and in revision of the manuscript. $J$ and $E F$ constructed the color variants of sfGFP, transformed thermophilic bacterial species with the plasmid DNA and analyzed the FP expression with the fluorescence microscope. AvS and EF performed in vitro characterization experiments of sfGFP variant proteins. All authors read and approved the final manuscript.

\section{Author details}

${ }^{1}$ Department of Molecular Genetics, Groningen Biomolecular Sciences and Biotechnology Institute, Centre for Synthetic Biology, University of Groningen, Nijenborgh 7, 9747 AG Groningen, The Netherlands. ${ }^{2}$ Laboratory of Microbiology, Wageningen University, Stippeneng 4, 6708 WE Wageningen, The Netherlands. ${ }^{3}$ Corbion, Arkselsedijk 46, 4206 AC Gorinchem, The Netherlands.

\section{Acknowledgements}

We thank Mariska van Hartskamp and Elleke Bosma for advices on preparation of competent cells and on transformation procedures. We thank Bauke Gaastra for initial help in preparation of the sfGFP mutational library. This work was financially supported by Corbion.

\section{Competing interests}

The authors declare that they have no competing interests. RvK is employed by the commercial company Corbion (Gorinchem, The Netherlands).

\section{Availability of data and materials}

All data generated or analyzed during this study are included in this published article (and its Additional files)

\section{Compliance with ethical guidelines}

Not applicable.

\section{Consent for publication}

Not applicable.

Ethics approval and consent to participate

Not applicable.

\section{Funding}

This work was financially supported by Corbion.

\section{Publisher's Note}

Springer Nature remains neutral with regard to jurisdictional claims in published maps and institutional affiliations.

Received: 18 August 2017 Accepted: 29 December 2017

Published online: 17 January 2018

\section{References}

1. Bartosiak-Jentys J, Hussein AH, Lewis CJ, Leak DJ. Modular system for assessment of glycosyl hydrolase secretion in Geobacillus thermoglucosidasius. Microbiology. 2013;159:1267-75.

2. De Maayer P, Brumm PJ, Mead DA, Cowan DA. Comparative analysis of the Geobacillus hemicellulose utilization locus reveals a highly variable target for improved hemicellulolysis. BMC Genom. 2014;15:836.

3. Bhalla A, Bischoff KM, Sani RK. Highly thermostable xylanase production from a thermophilic Geobacillus sp. Strain WSUCF1 utilizing lignocellulosic biomass. Front Bioeng Biotechnol. 2015;3:84.

4. Potprommanee L, Wang XQ, Han YJ, Nyobe D, Peng YP, Huang Q, Liu JY, Liao YL, Chang KL. Characterization of a thermophilic cellulase from Geobacillus sp. HTA426, an efficient cellulase-producer on alkali pretreated of lignocellulosic biomass. PLoS ONE. 2017:12:e0175004.

5. Bosma EF, van der Oost J, de Vos WM, van Kranenburg R. Sustainable production of bio-based chemicals by extremophiles. Curr Biotechnol. 2013;2:360-79.
6. Lemos LN, Pereira RV, Quaggio RB, Martins LF, Moura LMS, da Silva AR, Antunes LP, da Silva AM, Setubal JC. Genome-centric analysis of a thermophilic and cellulolytic bacterial consortium derived from composting. Front Microbiol. 2017;8:644.

7. Cripps RE, Eley K, Leak DJ, Rudd B, Taylor M, Todd M, Boakes S, Martin S, Atkinson T. Metabolic engineering of Geobacillus thermoglucosidasius for high yield ethanol production. Metab Eng. 2009;11:398-408.

8. Niu H, Leak D, Shah N, Kontoravdi C. Metabolic characterization and mod eling of fermentation process of an engineered Geobacillus thermoglucosidasius strain for bioethanol production with gas stripping. Chem Eng Sci. 2005:122:138-49.

9. Lin PP, Rabe KS, Takasumi JL, Kadisch M, Arnold FH, Liao JC. Isobutanol production at elevated temperatures in thermophilic Geobacillus thermoglucosidasius. Metab Eng. 2014;24:1-8.

10. Zhou J, Wu K, Rao CV. Evolutionary engineering of Geobacillus thermoglucosidasius for improved ethanol production. Biotechnol Bioeng 2016;113:2156-67.

11. Cordova LT, Antoniewicz MR. (13)C metabolic flux analysis of the extremely thermophilic, fast growing, xylose-utilizing Geobacillus strain LC300. Metab Eng. 2016;33:148-57.

12. Ahmad A, Hartman HB, Krishnakumar S, Fell DA, Poolman MG, Srivastava S. A Genome Scale Model of Geobacillus thermoglucosidasius (C56-YS93) reveals its biotechnological potential on rice straw hydrolysate. J Biotechnol. 2017;251:30-7.

13. Suzuki Y, Kishigami T, Inoue K, Mizoguchi Y, Eto N, Takagi M, Abe S. Bacillus thermoglucosidasius sp. nov., a new species of obligately thermophilic bacilli. Syst Appl Microbiol. 1983:4:487-95.

14. Nazina TN, Tourova TP, Poltaraus AB, Novikova EV, Grigoryan AA, Ivanova AE, Lysenko AM, Petrunyaka VV, Osipov GA, Belyaev SS, Ivanov MV. Taxonomic study of aerobic thermophilic bacilli: descriptions of Geobacillus subterraneus gen. nov., sp. nov. and Geobacillus uzenensis sp. nov. from petroleum reservoirs and transfer of Bacillus stearothermophilus, Bacillus thermocatenulatus, Bacillus thermoleovorans, Bacillus kaustophilus, Bacillus thermodenitrificans to Geobacillus as the new combinations G. stearothermophilus, G. th. Int J Syst Evol Microbiol. 2001;51:433-46.

15. Coorevits A, Dinsdale AE, Halket G, Lebbe L, De Vos P, Van Landschoot A Logan NA. Taxonomic revision of the genus Geobacillus: emendation of Geobacillus, G. stearothermophilus, G. jurassicus, G. toebii, G. thermodenitrificans and G. thermoglucosidans (nom. corrig., formerly 'thermoglucosidasius'); transfer of Bacillus thermantarcticus to the genus as $G$. thermantarcticus comb. nov.; proposal of Caldibacillus debilis gen. nov., comb. nov.; transfer of G. tepidamans to Anoxybacillus as A. tepidamans comb. nov:; and proposal of Anoxybacillus caldiproteolyticus sp. nov. Int J Syst Evol Microbiol. 2012;62:1470-85.

16. Aliyu H, Lebre P, Blom J, Cowan D, De Maayer P. Phylogenomic reassessment of the thermophilic genus Geobacillus. Syst Appl Microbiol. 2016;39:527-33.

17. Bosma EF, van de Weijer AH, van der Vlist L, de Vos WM, van der Oost J, van Kranenburg R. Establishment of markerless gene deletion tools in thermophilic Bacillus smithii and construction of multiple mutant strains. Microb Cell Fact. 2015:14:99.

18. Tominaga Y, Ohshiro T, Suzuki H. Conjugative plasmid transfer from Escherichia coli is a versatile approach for genetic transformation of thermophilic Bacillus and Geobacillus species. Extremophiles. 2016;20:375-81.

19. Hussein AH, Lisowska BK, Leak DJ. The genus Geobacillus and their biotechnological potential. Adv Appl Microbiol. 2015;92:1-48.

20. Kananaviciute R, Citavicius D. Genetic engineering of Geobacillus spp. J Microbiol Methods. 2015;111:31-9.

21. Taylor MP, Esteban CD, Leak DJ. Development of a versatile shuttle vector for gene expression in Geobacillus spp. Plasmid. 2008;60:45-52.

22. Reeve B, Martinez-Klimova E, de Jonghe J, Leak DJ, Ellis T. The Geobacillus plasmid set: a modular toolkit for thermophile engineering. ACS Synth Biol. 2016;5:1342-7

23. Pogrebnyakov I, Jendresen CB, Nielsen AT. Genetic toolbox for controlled expression of functional proteins in Geobacillus spp. PLOS ONE. 2017:12:e0171313.

24. Sheng L, Kovacs K, Winzer K, Zhang Y, Minton NP. Development and implementation of rapid metabolic engineering tools for chemical and fuel production in Geobacillus thermoglucosidasius NCIMB 11955. Biotechnol Biofuels. 2017:10:5. 
25. Palmer AE, Qin Y, Park JG, McCombs JE. Design and application of genetically encoded biosensors. Trends Biotechnol. 2011;29:144-52.

26. Zhang J, Jensen MK, Keasling JD. Development of biosensors and their application in metabolic engineering. Curr Opin Chem Biol. 2015;28:1-8.

27. Shimomura O, Johnson FH, Saiga Y. Extraction, purification and properties of aequorin, a bioluminescent protein from the luminous hydromedusan, Aequorea. J Cell Comp Physiol. 1962;59:223-39.

28. Prasher DC, Eckenrode VK, Ward WW, Prendergast FG, Cormier MJ. Primary structure of the Aequorea victoria green-fluorescent protein. Gene. 1992;111:229-33.

29. Tsien RY. The green fluorescent protein. Annu Rev Biochem. 1998;67:509-44

30. Stepanenko OV, Stepanenko OV, Kuznetsova IM, Verkhusha VV, Turoverov KK. Beta-barrel scaffold of fluorescent proteins: folding, stability and role in chromophore formation. Int Rev Cell Mol Biol. 2013;302:221-78.

31. Cranfill PJ, Sell BR, Baird MA, Allen JR, Lavagnino Z, de Gruiter HM, Kremers GJ, Davidson MW, Ustione A, Piston DW. Quantitative assessment of fluorescent proteins. Nat Methods. 2016;13:557-62.

32. Day RN, Davidson MW. The fluorescent protein palette: tools for cellular imaging. Chem Soc Rev. 2009;38:2887-921.

33. Chudakov DM, Matz MV, Lukyanov S, Lukyanov KA. Fluorescent proteins and their applications in imaging living cells and tissues. Physiol Rev. 2010;90:1103-63.

34. Remington SJ. Green fluorescent protein: a perspective. Protein Sci. 2011;20:1509-19.

35. Overkamp W, Beilharz K, Weme RD, Solopova A, Karsens H, Kovacs AT, Kok J, Kuipers OP, Veening JW. Benchmarking various green fluorescent protein variants in Bacillus subtilis, Streptococcus pneumoniae, and Lactococcus lactis for live cell imaging. Appl Environ Microbiol. 2013;79:6481-90.

36. Kovacs AT, van Hartskamp M, Kuipers OP, van Kranenburg R. Genetic tool development for a new host for biotechnology, the thermotolerant bacterium Bacillus coagulans. Appl Environ Microbiol. 2010;76:4085-8.

37. Kellner N, Schwarz J, Sturm M, Fernandez-Martinez J, Griesel S, Zhang W, Chait BT, Rout MP, Kuck U, Hurt E. Developing genetic tools to exploit Chaetomium thermophilum for biochemical analyses of eukaryotic macromolecular assemblies. Sci Rep. 2016;6:20937.

38. Pedelacq JD, Cabantous S, Tran T, Terwilliger TC, Waldo GS. Engineering and characterization of a superfolder green fluorescent protein. Nat Biotechnol. 2006;24:79-88.

39. Aliye N, Fabbretti A, Lupidi G, Tsekoa T, Spurio R. Engineering color variants of green fluorescent protein (GFP) for thermostability, pHsensitivity, and improved folding kinetics. Appl Microbiol Biotechnol. 2015;99:1205-16.

40. Blanchard K, Robic S, Matsumura I. Transformable facultative thermophile Geobacillus stearothermophilus NUB3621 as a host strain for metabolic engineering. Appl Microbiol Biotechnol. 2014;98:6715-23.

41. Bosma EF, van de Weijer AH, Daas MJ, van der Oost J, de Vos WM, van Kranenburg R. Isolation and screening of thermophilic bacilli from compost for electrotransformation and fermentation: characterization of Bacillus smithii ET 138 as a new biocatalyst. Appl Environ Microbiol. 2015:81:1874-83.

42. Kovacs AT, Eckhardt TH, van Hartskamp M, van Kranenburg R, Kuipers OP. Functional analysis of the ComK protein of Bacillus coagulans. PLoS ONE. 2013;8:e53471.

43. Sambrook J, Russell DW. Molecular cloning: a laboratory manual. 3rd ed. Cold Spring Harbor: Cold Spring Harbor Laboratory Press; 2001.

44. Eschenfeldt WH, Lucy S, Millard CS, Joachimiak A, Mark ID. A family of LIC vectors for high-throughput cloning and purification of proteins. Methods Mol Biol. 2009:498:105-15.

45. Heim R, Prasher DC, Tsien RY. Wavelength mutations and posttranslational autoxidation of green fluorescent protein. Proc Natl Acad Sci USA. 1994;91:12501-4

46. Wachter RM, Elsliger MA, Kallio K, Hanson GT, Remington SJ. Structural basis of spectral shifts in the yellow-emission variants of green fluorescent protein. Structure. 1998;6:1267-77.

47. Studholme DJ. Some (bacilli) like it hot: genomics of Geobacillus species. Microb Biotechnol. 2015;8:40-8.

48. Andrews BT, Schoenfish AR, Roy M, Waldo G, Jennings PA. The rough energy landscape of superfolder GFP is linked to the chromophore. J Mol Biol. 2007;373:476-90
49. Vedadi M, Niesen FH, Allali-Hassani A, Fedorov OY, Finerty PJ Jr, Wasney GA, Yeung R, Arrowsmith C, Ball LJ, Berglund H, et al. Chemical screening methods to identify ligands that promote protein stability, protein crystallization, and structure determination. Proc Natl Acad Sci USA. 2006;103:15835-40.

50. Ghosh K, Dill K. Cellular proteomes have broad distributions of protein stability. Biophys J. 2010;99:3996-4002.

51. Merkel JS, Regan L. Modulating protein folding rates in vivo and in vitro by side-chain interactions between the parallel beta strands of green fluorescent protein. J Biol Chem. 2000;275:29200-6.

52. Yang TT, Sinai P, Green G, Kitts PA, Chen YT, Lybarger L, Chervenak R, Patterson GH, Piston DW, Kain SR. Improved fluorescence and dual color detection with enhanced blue and green variants of the green fluorescent protein. J Biol Chem. 1998;273:8212-6.

53. Sastalla I, Chim K, Cheung GY, Pomerantsev AP, Leppla SH. Codonoptimized fluorescent proteins designed for expression in low-GC grampositive bacteria. Appl Environ Microbiol. 2009;75:2099-110.

54. Kaishima M, Ishii J, Matsuno T, Fukuda N, Kondo A. Expression of varied GFPs in Saccharomyces cerevisiae: codon optimization yields stronger than expected expression and fluorescence intensity. Sci Rep. 2016;6:35932

55. Scholz O, Thiel A, Hillen W, Niederweis M. Quantitative analysis of gene expression with an improved green fluorescent protein. p6. Eur J Biochem. 2000;267:1565-70.

56. Kane JF. Effects of rare codon clusters on high-level expression of heterologous proteins in Escherichia coli. Curr Opin Biotechnol. 1995;6:494-500

57. Yang TT, Cheng L, Kain SR. Optimized codon usage and chromophore mutations provide enhanced sensitivity with the green fluorescent protein. Nucleic Acids Res. 1996:24:4592-3.

58. Agashe D, Martinez-Gomez NC, Drummond DA, Marx CJ. Good codons, bad transcript: large reductions in gene expression and fitness arising from synonymous mutations in a key enzyme. Mol Biol Evol. 2013;30:549-60.

59. Curran KA, Leavitt JM, Karim AS, Alper HS. Metabolic engineering of muconic acid production in Saccharomyces cerevisiae. Metab Eng. 2013;15:55-66

60. Kudla G, Murray AW, Tollervey D, Plotkin JB. Coding-sequence determinants of gene expression in Escherichia coli. Science. 2009:324:255-8.

61. Komar AA. A pause for thought along the co-translational folding pathway. Trends Biochem Sci. 2009;34:16-24.

62. Ugrinov KG, Clark PL. Cotranslational folding increases GFP folding yield. Biophys J. 2010;98:1312-20.

63. Zhang G, Ignatova Z. Folding at the birth of the nascent chain: coordinating translation with co-translational folding. Curr Opin Struct Biol. 2011;21:25-31.

64. Kelkar DA, Khushoo A, Yang Z, Skach WR. Kinetic analysis of ribosomebound fluorescent proteins reveals an early, stable, cotranslational folding intermediate. J Biol Chem. 2012;287:2568-78.

65. Gorochowski TE, Ignatova Z, Bovenberg RA, Roubos JA. Trade-offs between tRNA abundance and mRNA secondary structure support smoothing of translation elongation rate. Nucleic Acids Res. 2015;43:3022-32.

66. Nedialkova DD, Leidel SA. Optimization of codon translation rates via tRNA modifications maintains proteome integrity. Cell. 2015;161:1606-18.

67. Umu SU, Dobson RC, Gardner PP. Avoidance of stochastic RNA interactions can be harnessed to control protein expression levels in bacteria and archaea. Elife. 2016:5:13479.

68. Stepanenko OV, Stepanenko OV, Kuznetsova IM, Uversky VN, Turoverov KK. Peculiarities of the super-folder GFP folding in a crowded milieu. Int J Mol Sci. 2016;17:1805.

69. Asial I, Cheng YX, Engman H, Dollhopf M, Wu B, Nordlund P, CornvikT. Engineering protein thermostability using a generic activity-independent biophysical screen inside the cell. Nat Commun. 2013;4:2901.

70. Chakravarty S, Varadarajan R. Elucidation of determinants of protein stability through genome sequence analysis. FEBS Lett. 2000;470:65-9.

71. Panja AS, Bandopadhyay B, Maiti S. Protein thermostability is owing to their preferences to non-polar smaller volume amino acids, variations in residual physico-chemical properties and more salt-bridges. PLoS ONE. 2015;10:e0131495.

72. Fukuda $\mathrm{H}$, Arai M, Kuwajima K. Folding of green fluorescent protein and the cycle3 mutant. Biochemistry. 2000;39:12025-32. 
73. Modarres HP, Mofrad MR, Sanati-Nezhad A. Protein thermostability engineering. RSC Advances. 2016;6:115252-70.

74. Pica A, Graziano G. Shedding light on the extra thermal stability of thermophilic proteins. Biopolymers. 2016;105:856-63.

75. Mitarai N, Pedersen S. Control of ribosome traffic by position-dependent choice of synonymous codons. Phys Biol. 2013;10:056011.

76. Shabalina SA, Spiridonov NA, Kashina A. Sounds of silence: synonymous nucleotides as a key to biological regulation and complexity. Nucleic Acids Res. 2013;41:2073-94.

77. Yu CH, Dang Y, Zhou Z, Wu C, Zhao F, Sachs MS, Liu Y. Codon usage influences the local rate of translation elongation to regulate co-translational protein folding. Mol Cell. 2015;59:744-54.

78. Quax TE, Claassens NJ, Soll D, van der Oost J. Codon bias as a means to fine-tune gene expression. Mol Cell. 2015;59:149-61.

79. Kiss C, Temirov J, Chasteen L, Waldo GS, Bradbury AR. Directed evolution of an extremely stable fluorescent protein. Protein Eng Des Sel. 2009;22:313-23.
80. Daas MJ, van de Weijer AH, de Vos WM, van der Oost J, van Kranenburg R. Isolation of a genetically accessible thermophilic xylan degrading bacterium from compost. Biotechnol Biofuels. 2016;9:210.

81. Lewis PJ, Marston AL. GFP vectors for controlled expression and dual labelling of protein fusions in Bacillus subtilis. Gene. 1999;227:101-10.

82. Cormack BP, Valdivia RH, Falkow S. FACS-optimized mutants of the green fluorescent protein (GFP). Gene. 1996;173:33-8.

83. Martin B, Granadel C, Campo N, Henard V, Prudhomme M, Claverys JP. Expression and maintenance of ComD-ComE, the two-component signal-transduction system that controls competence of Streptococcus pneumoniae. Mol Microbiol. 2010;75:1513-28.

84. Milde S. Superfolder GFP driven by T7 promoter. Part:BBa_1746909. IGEM registry of standard biological parts. Cambridge: The International Genetically Engineered Machine (iGEM) Foundation; 2008.

\section{Submit your next manuscript to BioMed Central and we will help you at every step:}

- We accept pre-submission inquiries

- Our selector tool helps you to find the most relevant journal

- We provide round the clock customer support

- Convenient online submission

- Thorough peer review

- Inclusion in PubMed and all major indexing services

- Maximum visibility for your research

Submit your manuscript at www.biomedcentral.com/submit 